\title{
Weaving disciplines to conceptualize a regenerative food system
}

\author{
Sara El-Sayed ${ }^{*} *$ and Scott Cloutier ${ }^{b}$ \\ Arizona State University
}

Submitted October 2, 2020 / Revised December 25, 2020, May 13, August 7, and September 23, 2021 /

Accepted September 23, 2021 / Published online January 21, 2022

Citation: El-Sayed, S., \& Cloutier, S. (2022). Weaving disciplines to conceptualize a regenerative

food system. Journal of Agriculture, Food Systems, and Community Development, 11(2), 23-51.

https://doi.org/10.5304/jafscd.2022.112.003

Copyright (C) 2022 by the Authors. Published by the Lyson Center for Civic Agriculture and Food Systems. Open access under CC-BY license.

\begin{abstract}
Traditional and Indigenous practices worldwide have aimed to create sustainable and regenerative food systems guided by nature and based on reciprocal relationships between humans and nonhumans. Unfortunately, not all sustainable food system approaches, while striving for less harm rather than a net-positive impact, have considered indigenous knowledge or justice for small-scale producers and their communities. This paper contextualizes and conceptualizes a regenerative food system that addresses harm to the planet and people while creating a net positive impact by integrating a different research and practice
\end{abstract}

a * Corresponding author: Sara El-Sayed, Post-doctoral Scholar, School for the Future of Innovation in Society, Arizona State University; Wrigley Hall, 800 Cady Mall; Tempe, AZ 85281 USA; $\underline{\text { sara.elsayed@asu.edu }}$

b Scott Cloutier, Assistant Professor, School of Sustainability, Arizona State University; scott.cloutier@asu.edu

\section{Author Contributions}

Conceptualization and draft preparation was by Author One; overall review and editing were by Author Two. Funding acquisition was by El-Sayed. All authors have read and agreed to the published version of the manuscript. framework. First, we offer a positionality statement, followed by our definition and characterization of a regenerative food system; then we compare and contrast conventional and sustainable approaches, making a case for the need to create space for a regenerative food system. Next, we provide a framework of 13 principles for a regenerative food system by weaving the natureinspired biomimicry framework of Life's Principles (LPs) with Traditional Ecological Knowledge (TEK) principles, while verifying these practices as they are used among small-scale Indigenous producers from selected arid regions, primarily the U.S. Southwest.

\section{Keywords}

Food Systems, Biomimicry, Traditional Ecological Knowledge, Indigenous Knowledge, Arid Regions

\section{Funding Disclosure}

This research was partially funded by the Neely Foundation Food and Agriculture Sustainability grant, an internal Arizona State University grant.

\section{Conflicts of Interest}

The authors declare no conflict of interest. 


\section{Introduction}

If we are looking for models of self-sustaining communities, we need look no further than an old-growth forest. Or the old-growth cultures they raised in symbiosis with them.

— Robin Wall Kimmerer (2013, p. 284), Potawatomi Nation

I, Sara El-Sayed, am originally from Egypt and have lived in the American Southwest since 2017. My experiences in collaboration with small-scale producers in both these places have stimulated my interest in, and provided me with insight into, identifying common characteristics of regenerative food systems in arid regions. My research is influenced by both Indigenous and intersectional ecofeminist research (Ackerly \& True, 2010; Harcourt, 2017; Merchant, 1996; Trauger, 2017) that ensures relational accountability, in which meaning is based on a community's and individual's experience of being respectful and accountable (Wilson, 2008). Human understandings of the environment are socially situated within narratives based on people's lived experiences and socio-political engagements (Harcourt, 2017). Within this paradigm, I have studied producers who are creating innovative and frugal practices which ensure that seeds are adapted to their harsh environments, preserve and ferment foods while collaborating with microbial life, and hold rituals and ceremonies connecting different generations with food, all while safeguarding traditional cultural and spiritual connections (Adamson et al., 2016; Portman, 2018; Wilson, 2008). I, Scott Cloutier, am originally from New Hampshire and have spent countless hours in New England forests and gardens. My intellectual work focuses on practices that simultaneously regenerate ecological systems and human happiness while honoring our spiritual connection and service to the land. I have worked globally with small-scale farmers ranging from dairy farmers to foresters to local mom-and-pop vegetable stands and have found that many of these practitioners have been inspired by regenerative development practices. Together, we are integrating our academic and practical experience with regenerative development theory to propose a theoretical and practical frame- work while honoring the voices and wisdom of small-scale producers. This paper's eco-feminist approach acknowledges the value of centering one's positionality and bringing narratives into academia (Haraway, 2008; Ilmonen, 2020; Trauger, 2017) through blending storytelling with academic prose.

Because of the lack of attention to regenerative food system frameworks in academic literature, this paper aims to create a conceptual framework that defines a regenerative food system and identifies its characteristics. The paper will (1) contextualize how a regenerative food system fits within the larger context of modern food systems and builds on sustainability concepts, (2) define a regenerative food system by building on Dahlberg's (1993) regenerative food system definition, and (3) delineate a conceptual framework that emerges through an iterative process. The research is inspired by tools in grounded theory methodologies (Charmaz \& Belgrave, 2019) that explore practices drawn from nature-inspired design (Baumeister, 2017; Benyus, 1997) and Traditional Ecological Knowledge (TEK) (Berkes, 1993; Kimmerer, 2002; Whyte, 2013). We also draw on findings from a series of interviews and workshops. Specifically, we compare and contrast food-related aspects of biomimicry Life's Principles (LPs) (Baumeister, 2017) with TEK principles (Hoover \& Mihesuah, 2019; Shilling, 2018), and compare them with thematic findings from field research conducted in 20192020. The field research was conducted in the arid U.S. Southwest and consisted of interviews across the food chain with self-identified regenerative practitioners who are small-scale producers, primarily from rural communities, as well as data collection and experience-gathering from various Indigenous food workshops in 2019-2020. The collected data supports further insight into potential frameworks to support the work of regenerative scholars and academics across the food system.

A food system is the transformation of food across a chain of activities from production, processing, marketing, and consumption to waste management (Ericksen, 2008). We compare three concepts as ways of thinking about food systems: the prevailing industrial system, which began in the 1900s; the 1990s sustainable food system concept 
stemming from the 1980s sustainable agriculture movement, and not yet realized; and, most recently, the regenerative food system concept. Of the three food system concepts, the industrial is widely practiced and prevalent, while the sustainable has not been realized on significant scales but has generated a myriad of alternative paths and practices (e.g., organic farming, community supported agriculture [CSA], farmers markets) that have attempted to counter the negative impacts of the industrial food system (Rhodes, 2017). The regenerative food system concept is just beginning to emerge in literature and practice-although it has long roots in traditional cultures-and is what we propose can enhance sustainable food system goals. Specifically, we suggest that concepts of regeneration can be blended with small-scale traditional production drawing on inspiration from nature. Thus, when we refer to a sustainable food system, we are speaking of it as a conceptual idea not yet realized; the same is true for the regenerative food system concept.

Rural small-scale producers, who number about 2.1 billion worldwide (Steward et al., 2014), provide $60 \%$ of global food needs (Patel, 2012; Rhodes, 2017). However, they lack an equal seat at the table in defining what constitutes good farming or good food in the dominant modern food system (Patel, 2012). At the same time, producers in arid regions, known as drylands, face even bigger strains due to climate changes (Blanco, et al., 2017; United Nations, 2010). Some of these producers have developed innovative ideas to adapt to these conditions and can offer valuable lessons in making our food system more diverse and resilient.

\section{Food System Concepts: Shifting from Industrial and Moving Beyond Sustainable to Regenerative}

The industrial food system, rooted in capitalism, grew in reaction to a food-insecure population but has become a means of expanding corporate power through cheap and abundant food (Baret, 2018; Patel \& Moore, 2017). A handful of scientists, backed by a conglomerate of institutions, innovated systems to increase production. Borlaug, often referred to as the father of the Green Revolution, focused on grain intensification, and Haber and Bosch invented industrial-scale ammonia production for the production of synthetic fertilizers (Dunn, 2017). This current system's growth is based largely on monocultures, synthetic fertilizers, pesticides, and genetically modified crops, which have led to unintended consequences and a path dependent on ever-growing corporations (Bausch et al., 2015). The industrial food system has resulted in depleted soils, pollutants leaching into water sources, and a commodity-based economy that has left small-scale producers unable to compete in a global market (Carlisle, 2016; Patel, 2012; Portman, 2018; Trauger, 2017). This "food regime" (Glennie \& Alkon, 2017; Portman, 2018) is based on a neoliberal economy, consisting of profitfocused entities that hold both resources (e.g., patents by a few large agribusinesses) and decisionmaking power (Patel \& Moore, 2017; Rhodes, 2017).

Consequently, the dominant system overproduces food (Food and Agriculture Organization of the United Nations [FAO], 2015) and simultaneously results in poor nutrition and an obesity epidemic while one billion people are hungry (Birkeland, 2008; Patel, 2012). To address these issues, starting in the 1960s the U.S. organic movement began paving the way for sustainable agriculture, eventually pushing for legislation in the early 1980s that called for alternative and sustainable food system practices (Youngberg \& DeMuth, 2013). On the international stage, beginning in the late 1980s, farmers from organizations such as Via Campesina in the food sovereignty movement, supported by academics and international organizations such as the $\mathrm{FAO}$, had a growing public interest in alternative practices for a more sustainable food system (Dahlberg, 1993; Kloppenburg et al., 2000; Rhodes, 2017).

The sustainable food system concept emerged as a critique to counter the industrialized system, by promoting food security under uncertain socioecological conditions, and ensuring food for current generations without compromising future generations' ability to provide for their own needs (Eakin et al., 2017; Rhodes, 2017; World Commission on Environment and Development, 1987). A plethora of alternative solutions can be loosely grouped as "sustainable food systems," although 
defining sustainability remains challenging (Kloppenburg et al., 2000). The term has been applied to but is not limited to sustainable agriculture practices that build on organic agricultural production (Kloppenburg et al., 2000; Youngberg \& DeMuth, 2013), conservation farming, labeling, land intensification (Eakin et al., 2017), community gardens (DeLind, 2011), market innovations, diversified diets, nutrition assistance programs, and raised awareness of food justice (Eakin et al., 2017). Over time, these definitions have been contested as some of these practices have proven to be unsustainable. For example, some organic products are grown as monocultures, others are using patented seeds, and others use soils that have lost their organic matter content (Leifeld, 2012).

Sustainability, from the Latin sustener, "to hold" (Shilling, 2018), aims at causing less harm (Rhodes, 2012), absorbing perturbations, and maintaining function (Thompson \& Scoones, 2009). Over time the concept has expanded and integrated three pillars of sustainable development: ecological, social, and economic (World Commission on Environment and Development, 1987). With regard to food systems, however, these pillars have not held equal status. Ecologically based agricultural practices, concerned only with farming practices and not addressing issues of hunger and injustice for small-scale producers, women, and people of color, have been criticized as insufficient (Allen \& Sachs, 1991; Dahlberg, 1994; Kloppenburg et al., 2000). Machinery and cheap labor subsidize the industry and eventually replace the small-scale farmers who cannot compete within the economies of scale (Patel \& Moore, 2017), so that alternatives still fall short. Labels such as organic and fair trade have become co-opted and greenwashed into the neoliberal pursuit of economic gain (Edelman et al., 2014; Trauger, 2017). Integrated pest management, which avoids synthetic pesticides, still does not consider how to create more closed-loop systems. Sustainable food system approaches are also often developed without small-scale farmers in mind (Rigby \& Cáceres, 2001). Moreover, while the various alternative forms fill a vital niche in the sustainable food systems framework, they do not necessarily address the role that small-scale pro- ducers and their communities and cultures play, nor the importance of cultural food diversity or the physiological differences in what people can eat (Guthman, 2014). Many sustainable alternatives fall short in that they offer solutions that exclude smaller traditional farmers and perpetuate inequalities in food access and control of the food system. Thus, yet another shift has emerged: a movement toward the concept of a regenerative food system, driven by community-based, small-scale, and Indigenous producers and other proponents of ecologically based food systems.

Unlike the reductionist, positivist approach embraced by industrial food systems (Berkes, 2018), the regeneration narrative embraces complexity. The path to regeneration is one of positive and regenerative development (Birkeland, 2008; Gibbons et al., 2018), reciprocity, restoration, and life promotion (Gibbons et al., 2018) with a netpositive impact (Elevitch et al., 2018; Hes \& du Plessis, 2015; Mang \& Reed, 2015; Rhodes, 2012). The concept of regeneration is used by farmers and communities to define a system that is not just sustainable but bountiful. It is a pathway that is inclusive of small-scale and traditional practices. Frameworks exist for regeneration, such as regenerative development, a process in which human communities and economic activities mutually benefit lifeinducing processes (Mang \& Reed, 2012) and manifest in the full potential of improved health for the whole system (Gibbons et al., 2018). Another framework for regenerative agriculture or holistic management (Savory \& Duncan, 2016) aims to enhance the ecosystem services of the land (du Plessis \& Brandon, 2015), with a focus on improving the health and quality of soils, water, and vegetation (Rhodes, 2015; Savory \& Duncan, 2016). However, a regenerative food system framework has not been fully developed. Dahlberg (1993) was the first to define a regenerative food system across the value chain. Our research builds and expands on this definition while also providing an integrated framework to support it.

Table 1 illustrates the three food systems (industrial, sustainable, and regenerative) introduced above and some of their associated worldviews and narratives. 
Table 1. Selected Industrial, Sustainable, and Regenerative Food System Worldviews and Narratives

\begin{tabular}{|c|c|c|c|}
\hline & Industrial/Conventional & Sustainable/Alternative & Regenerative \\
\hline Worldview & $\begin{array}{l}\text { 1. Man over nature, domination } \\
\text { (Patel, 2012), patriarchal } \\
\text { 2. Neoliberal economy and capi- } \\
\text { talism (Patel, 2012; Portman, } \\
\text { 2018) } \\
\text { 3. Commodity driven, } \\
\text { exploitative (Beus \& Dunlap, } \\
\text { 1990; Carlisle, 2016) } \\
\text { 4. Linear approach (Jackson, } \\
\text { 2010) }\end{array}$ & $\begin{array}{l}\text { - Stewards of the land } \\
\text { - May work in a complementary } \\
\text { way with a neoliberal economy } \\
\text { (Edelman et al., 2014; Trauger, } \\
\text { 2017) } \\
\text { - Foods are organic or sustain- } \\
\text { able, or produced fairly } \\
\text { - Cyclical approach }\end{array}$ & $\begin{array}{l}\text { - Reciprocal relations } \\
\text { - Eco-feminist and Indigenous } \\
\text { - Decentralized small-scale } \\
\text { - Spiral approach }\end{array}$ \\
\hline Narratives & $\begin{array}{l}\text { End hunger. Provide sufficient, } \\
\text { cheap food for a growing popu- } \\
\text { lation (Baret, 2018) } \\
\text { - Incentivizing monocultures, } \\
\text { chemical fertilizers, and } \\
\text { pesticides for efficiency } \\
\text { - Standardization for food safety } \\
\text { - Increasing profits and sales } \\
\text { - Waste does not factor into the } \\
\text { system unless it is profitable }\end{array}$ & $\begin{array}{l}\text { - A three-pronged approach with } \\
\text { goals of balancing between } \\
\text { nature, society, and the } \\
\text { economy } \\
\text { - Organic farming, although at } \\
\text { times grown in monocultures } \\
\text { (Rigby \& Cáceres, 2001) } \\
\text { - Uses alternative labeling, } \\
\text { organic, fair trade } \\
\text { - Consumer education is critical } \\
\text { - Aims at closing the nutrient } \\
\text { loop }\end{array}$ & $\begin{array}{l}\text { - Whole-systems approach } \\
\text { creating reciprocal } \\
\text { relationships } \\
\text { - } \text { Creating net-positive impact, } \\
\text { carbon capturing, increasing } \\
\text { biomass, cycling waste, and } \\
\text { enhancing ecosystem } \\
\text { services (Rhodes, 2017; } \\
\text { Soloviev \& Landua, 2016) } \\
\text { - Creating alternative } \\
\text { certifications that are } \\
\text { community-based } \\
\text { - Restoring cultural heritage } \\
\text { and identity }\end{array}$ \\
\hline
\end{tabular}

\section{Methods}

Our work was completed in four interconnected, nonlinear, approaches: (1) an iterative literature review to establish a baseline of regenerative food systems definitions and conceptualizations; (2) the integration of two relevant regenerative concepts that emerged from the literature: Life's Principles (LPs) and Traditional Ecological Knowledge (TEK); (3) a series of interviews and workshop participation to validate the integration; and (4) data analysis and coding of the results from steps 1-3. Our methods are grounded in qualitative techniques and also loosely guided by elements of grounded theory (Charmaz \& Belgrave, 2019). This includes data analysis aimed at developing theory through an iterative process, with data acquisition guiding where to find the next using theoretical sampling and literature review. For example, a paper might have led to the development of a new regenerative theory. Or one interview might have led to an interview with a new producer or following the origination of a native seed/regenerative practice. Whether reviewing literature, interview transcripts, workshop content, or mapping con- cepts into LPs and TEK, a process of memoing, taking notes, and analyzing the data, from which emergent themes arose (Charmaz \& Belgrave, 2019; Tie et al., 2019) was completed.

(1) Literature Review and Definition Generation. The literature review was an iterative process seeking regenerative food system theories using Google Scholar, Web of Science, and Scopus. Initial keywords included 'regenerative agriculture,' 'regenerative development,' 'agroecology,' 'permaculture,' and 'food system sustainability.' Literature was drawn from peer-reviewed articles as well as online publications from various institutions (e.g., the Land Institute and Savory Institute) (see Table A1 in Appendix A). Any literature mentioning regenerative approaches to food production or those with similar principles and definitions were included in our study. Content was cross-compared, collated, and clustered, resulting in some baseline principles (Figure 1). Our initial findings were also organized into related themes, which were then used to further define a regenerative food system.

(2) Weaving LPs and TEK. Regardless of the principle or themes, the initial literature review 


\section{Figure 1. Five-step Flow Process for the Conceptual Framework of a Regenerative Food System}

The five steps are: (1) Establishing baseline principles by drawing on extant literature (Table 1); (2) Extrapolating an overarching regenerative food system definition; (3) Focusing on Life's Principles circular diagram of 26 principles (Biomimicry 3.8 framework), and a circular diagram representing the Traditional Ecological Knowledge diagram developed in 2000 by Turner et al. (Appendix C, Figure C1); (4) Comparing emergent themes with literature and weaving LPS with TEK; and (5) Developing a spiral framework for a regenerative food system.

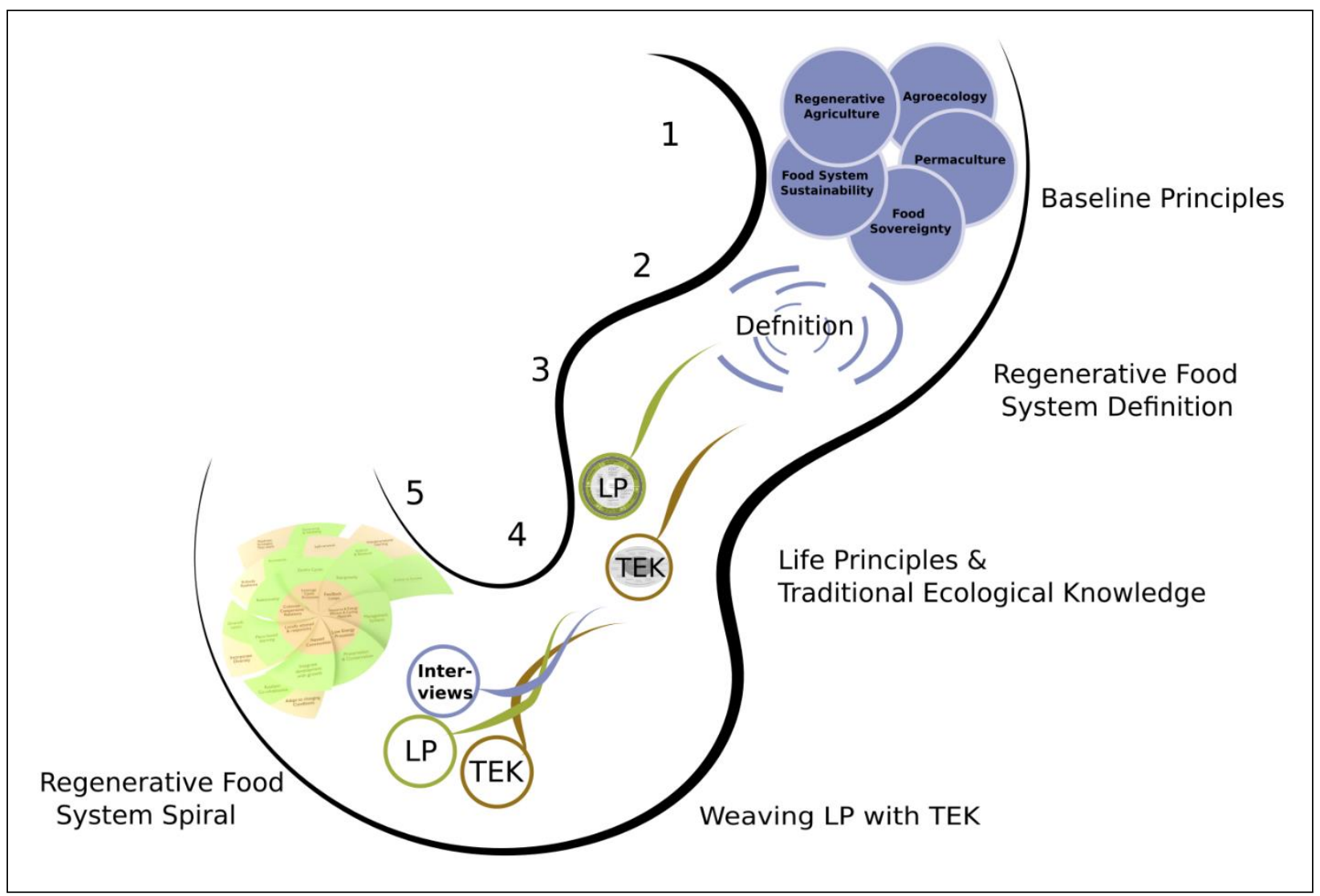

revealed that regenerative approaches often emulate natural systems and/or draw on traditional practices. Exploring these findings led us to two existing frameworks: Life's Principles from Biomimicry (accounting for nature emulation) and Traditional Ecological Knowledge (accounting for traditional practices). We decided to integrate the two to make a more comprehensive regenerative food systems research and practice-based framework. The process involved a weaving process (integration) through several iterations of matching principles from both LPs and TEK, eliminating others, and aligning the frameworks to define and characterize a regenerative food system. The process was achieved by revisiting literature, and the framework was validated by discussing it with food systems experts and practitioners in interviews and as part of attending a series of workshops.

3. Interviews and Workshops. In total, 24 semistructured interviews were conducted through purposive sampling, along with eight workshops attended (by El-Sayed) on Indigenous foodways, to integrate the findings more deeply from the methods above (see Table 2 and Table D1 in Appendix $\mathrm{D}$ for details on the workshops). Given that TEK is relatively new to academia, especially as it relates to food, the workshops provided more in-depth context and intense engagement (Ahmed \& Asraf, 2018; Ørngreen \& Levinsen, 2017). The workshops were led by expert panelists working in regenerative and sustainable food production, including both scholars and practitioners. Rich workshops 
Table 2. Interviews Conducted and Workshops Attended in the Course of the Research

\begin{tabular}{|c|c|c|c|}
\hline \multirow{13}{*}{ Interviews (24) } & \multirow{4}{*}{$\begin{array}{l}\text { Jobs (interviews fit } \\
\text { several categories) }\end{array}$} & Farmer/Gardener & 11 \\
\hline & & Processing & 4 \\
\hline & & Chef/Cook & 8 \\
\hline & & Educator & 17 \\
\hline & \multirow{3}{*}{ Race } & Native American & 8 \\
\hline & & White American & 8 \\
\hline & & Other & 8 \\
\hline & \multirow{2}{*}{ Gender } & Female & 18 \\
\hline & & Male & 6 \\
\hline & \multirow{4}{*}{ Location } & Northern Arizona & 7 \\
\hline & & Southern Arizona & 11 \\
\hline & & Southwest (not Arizona) & 3 \\
\hline & & North Africa & 2 \\
\hline \multirow{13}{*}{ Workshops (8) } & \multirow{3}{*}{ Themes } & Indigenous food systems & 4 \\
\hline & & Traditional processing practices & 2 \\
\hline & & Rights of Nature & 2 \\
\hline & \multirow{4}{*}{ Number of days/time } & 1 hour & 3 \\
\hline & & 1 day & 2 \\
\hline & & 2 days & 2 \\
\hline & & 10 days & 1 \\
\hline & \multirow{3}{*}{ Format of workshop } & Online & 3 \\
\hline & & Lecture & 3 \\
\hline & & Interactive workshops & 2 \\
\hline & \multirow{3}{*}{ Author engagement } & Listener & 5 \\
\hline & & Active-Participant & 1 \\
\hline & & Volunteer & 2 \\
\hline
\end{tabular}

notes (memos, notes, photos, video, and conversations) were also taken by El-Sayed to assess the validity of the topic (Lincoln et al., 1985). Artisanal and Indigenous producers working across the food system were interviewed via a snowball sampling process whereby they and the themes that emerged suggested the next interviews. Recorded interviews included open-ended questions and field observations, infused with arts-based games (e.g., visualization exercises and walk and talk) (Lerman, 2018). Subsequent workshops attended were a mix of inperson and online and were based on recommendations from interviewees; notes and photos were taken at each one. The longest workshop was an in-person 10-day Indigenous Sustainable Communities Design Course (ISCDC) run by Indigenous educators Clayton Brascoupe and Louie Hena. 4. Analysis to Finalize the Regenerative Food Systems Framework. To further enhance the inclusion or elimination of the principles from the integration of LPs and TEK, interview transcripts, workshop notes and transcripts, field notes, and pictures were imported into the data analysis tool MAXQDA (Version 3, VERBI Software, 2020). Here, in vivo coding and principles-based coding were completed. The concepts extrapolated from the interviews and workshops revealed many themes, which were classified into smaller categories and then compared to the principles identified from the literature in step 1 . The wealth of information and practices found across the interviews and workshops suggest that the principles in the literature and those from the integration of LPs and TEK are supported by current examples and practices (Figure 2; Table 3). All findings were integrated to create the regenerative food systems framework, shared below.

\section{Results}

Our results (Figure 1) are shared in five steps: (1) the findings from the literature review and the initial emergence of related themes (nature-inspired and traditional knowledge) and principles; (2) an enhanced definition for a regenerative food system; (3) the process of weaving together LPs and TEK; and (4) the development of a conceptual framework, based on comparing LPs and TEK principles with transcripts from interviews and workshops. The framework is illustrated in the 


\section{Figure 2. Regenerative Food System Spiral}

This represents the intersection between Traditional Ecological Knowledge (TEK) (brown) and Life's Principles (LPs) (green). The internal spiral is the base of 7 principles, the first tier is the expansion over time (one to two generations), and the second tier is the expansion over more time (across many generations). The spiral is a recurring pattern and symbol both in nature and in Indigenous communities, showing an optimal growth form.

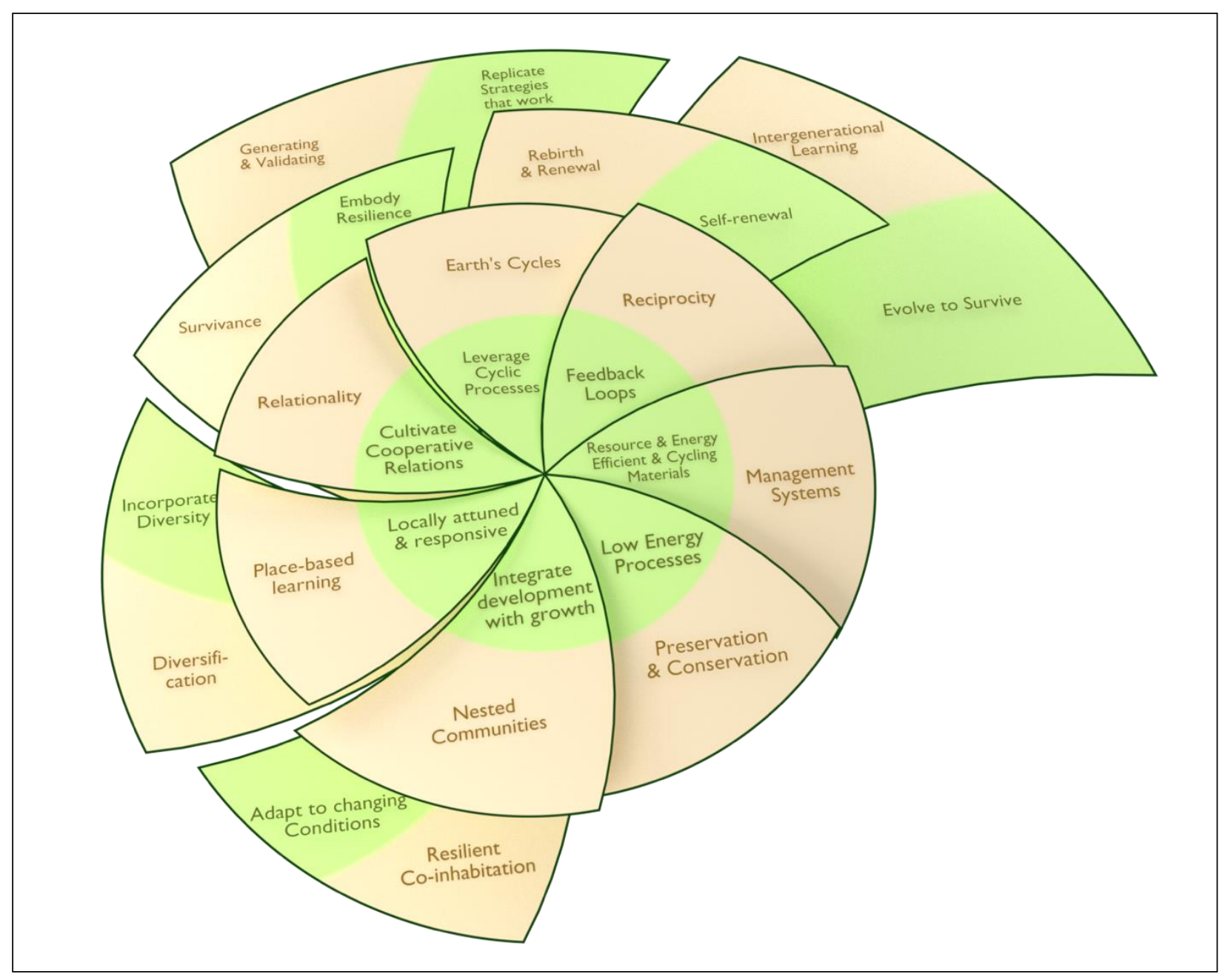

form of a spiral highlighting the most significant characteristics of a regenerative food system (Figure 2).

\section{Establishing Baseline Regeneration Principles}

The baseline principles were extrapolated from the literature, as described in the methods above, and mainly involved two themes: nature-inspired solutions (e.g., nutrient cycling, incorporating diversity, cooperation) and traditional practices (e.g., social justice for small-scale producers, place-based education, and a whole-system approach).

\section{Defining a Regenerative Food System}

Our definition of a regenerative food system is adapted from Dahlberg (1993). We propose an enhanced definition that builds on research based on both Indigenous knowledge and nature-inspired design. In addition, it included some of the aspects learned from our interviews and the workshops attended by El Sayed.

We define a regenerative food system as a whole-system approach to food that uses placebased education (Coté, 2019; Jackson \& Jensen, 2018; Kimmerer, 2002; Mang \& Reed, 2012), 
Table 3. LPs and TEK Definitions in Relation to Food Systems and Corresponding Examples

Numbers correspond to numbers in the discussion section.

\begin{tabular}{|c|c|c|c|}
\hline Biomimicry LP & TEK Principles & Definition in relation to food system & Practice or Example \\
\hline $\begin{array}{l}\text { 1. Locally attuned and } \\
\text { responsive }\end{array}$ & Place-based knowledge & $\begin{array}{l}\text { Food production that fits the immediate environment, } \\
\text { through generational experience based on place. }\end{array}$ & $\begin{array}{l}\text { - Being a nativore and connecting to ancestral foods } \\
\text { - Building a local food economy }\end{array}$ \\
\hline $\begin{array}{l}\text { 2. Cultivating cooperative } \\
\text { relationships }\end{array}$ & Relationality & $\begin{array}{l}\text { Symbiotic mutualisms that strengthen relations } \\
\text { among humans, nonhumans, spiritual entities, and } \\
\text { landscapes. }\end{array}$ & $\begin{array}{l}\text { - Introducing oneself and one's ancestry (Wilson, } \\
\text { 2008) } \\
\text { - Facilitating the growth of other organisms, including } \\
\text { pollinators, microbes, and fungi }\end{array}$ \\
\hline $\begin{array}{l}\text { 3. Leverage cyclic } \\
\text { processes }\end{array}$ & Cycles of the Earth & $\begin{array}{l}\text { Taking advantage of phenomena that repeat } \\
\text { themselves, food practices based on seasons, } \\
\text { ceremonies, and festivals. }\end{array}$ & $\begin{array}{l}\text { - Periodic Zuni bowls and dykes to divert seasonal } \\
\text { waters } \\
\text { - Cosmology-related rituals, including fasts } \\
\text { - Biodynamic farming practices }\end{array}$ \\
\hline 4. Feedback loops & Reciprocity & $\begin{array}{l}\text { Food production that embed self-regulating systems } \\
\text { and tight feedbacks, including reciprocity through } \\
\text { gifts. }\end{array}$ & $\begin{array}{l}\text { - Honorable harvest (Kimmerer, 2002) } \\
\text { - Gift economy } \\
\text { - Hopi grow corn protected deep in the ground and } \\
\text { corn reciprocates by producing food }\end{array}$ \\
\hline $\begin{array}{l}\text { 5. Readily available } \\
\text { materials/energy and } \\
\text { recycle all materials }\end{array}$ & Management systems & $\begin{array}{l}\text { Systems based on a deep understanding of both local } \\
\text { and readily available resources, and how to recycle } \\
\text { energy and resources. }\end{array}$ & $\begin{array}{l}\text { - Hopi dryland farming relies on rain, hard work, and } \\
\text { prayer (Wall \& Masayesva, 2019). } \\
\text { - Nahuatl 'quauhtalli,' rotten wood turned into rich, } \\
\text { soft soil (Peña, 2019). }\end{array}$ \\
\hline 6. Low-energy processes & $\begin{array}{l}\text { Preservation and } \\
\text { conservation }\end{array}$ & $\begin{array}{l}\text { Techniques that use low and available energy sources, } \\
\text { including strategies of food storage and preservation } \\
\text { for times of stress. }\end{array}$ & $\begin{array}{l}\text { - Fermentation of foods such as pickles, kombucha, } \\
\text { and kishk. } \\
\text { - Using passive energy such as gravity, net, and pan } \\
\text { farming }\end{array}$ \\
\hline $\begin{array}{l}\text { 7. Integrate development } \\
\text { with growth }\end{array}$ & Nested communities & $\begin{array}{l}\text { Investing optimally to promote both development and } \\
\text { growth based on nested elements that are built from } \\
\text { the bottom up. }\end{array}$ & $\begin{array}{l}\text { - Small bands organize into intricate structures } \\
\text { - O'odham people built on Hohokom canals, and } \\
\text { stabilized rivers by growing agave and century plants } \\
\text { (Nabhan, 2013) }\end{array}$ \\
\hline $\begin{array}{l}\text { 8. Adapt to changing } \\
\text { conditions }\end{array}$ & Resilient co-habitation & $\begin{array}{l}\text { Responding to dynamic contexts over time, and } \\
\text { producing foods adaptable to changes in climate; the } \\
\text { biosphere provides the rules and humans use trial and } \\
\text { error to adapt to the socio-ecological system. }\end{array}$ & $\begin{array}{l}\text { - Maintaining living seed banks } \\
\text { - Drought-tolerant crops } \\
\text { - California tribes managing forests via controlled } \\
\text { ceremonial fires based on trial and error }\end{array}$ \\
\hline 9. Incorporate diversity & Diversification & $\begin{array}{l}\text { Incorporating multiple forms, processes, and systems, } \\
\text { such as diverse species, multiple rotations, } \\
\text { successions, and guilds, and creating a diverse diet. }\end{array}$ & $\begin{array}{l}\text { - Growing polycultures (Three Sisters) } \\
\text { - Encouraging perennials } \\
\text { - Seasonal and ceremonial foods }\end{array}$ \\
\hline
\end{tabular}




\begin{tabular}{|c|c|c|c|c|}
\hline 10. & Self-renewal & Rebirth/renewal & $\begin{array}{l}\text { Maintaining integrity through self-renewal, increasing } \\
\text { hybrid vigor of plants and animals, as well as through } \\
\text { rituals such as spiritual ceremonies. }\end{array}$ & $\begin{array}{l}\text { - Smoke ceremonies for cleansing and detoxification } \\
\text { - Succession management, holistic grazing, and herd } \\
\text { rotations (the Sahel) }\end{array}$ \\
\hline 11. & $\begin{array}{l}\text { Resilience through } \\
\text { variation, redundancy, } \\
\text { and decentralization }\end{array}$ & Survivance & $\begin{array}{l}\text { Resilient food systems and survivance, withstanding } \\
\text { environmental and/or economic disturbances by } \\
\text { incorporating variation, decentralization, and an active } \\
\text { sense of presence by keeping stories alive. }\end{array}$ & $\begin{array}{l}\text { - The Gileños/Pimas use double and triple cropping, } \\
\text { harvest wild crops, and fish and hunt (Rea, 1997) } \\
\text { - The Jebilya of the South Sinai have fruit forests, } \\
\text { raise sheep, and tell stories through poetry }\end{array}$ \\
\hline 12. & $\begin{array}{l}\text { Replicate strategies } \\
\text { that work }\end{array}$ & $\begin{array}{l}\text { Generating, validating, } \\
\text { and interpreting }\end{array}$ & $\begin{array}{l}\text { Repeating successful food production strategies and } \\
\text { traditions observed from patterns in nature, } \\
\text { interpreted and replicated. }\end{array}$ & $\begin{array}{l}\text { - Telling food stories and songs marking pivotal } \\
\text { moments or teaching lessons } \\
\text { - Selecting and passing down drought-tolerant seeds }\end{array}$ \\
\hline 13. & Evolve to survive & $\begin{array}{l}\text { Intergenerational } \\
\text { learning }\end{array}$ & $\begin{array}{l}\text { Intergenerational learning from ancestors to posterity, } \\
\text { by telling stories and poetry, songs, and dreams, } \\
\text { embodying information that allows for the endurance } \\
\text { of food practices. }\end{array}$ & $\begin{array}{l}\text { - Maintaining knowledge for seven generations: three } \\
\text { generations back, the present, and three } \\
\text { generations forward, such as through } \\
\text { apprenticeship } \\
\text { - Transitioning from annual staples to perennial crops } \\
\text { (Jackson \& Jensen, 2018) }\end{array}$ \\
\hline
\end{tabular}

integrates traditional agroecological knowledge with modern practices (Altieri et al., 2011), and adopts nature-inspired solutions (Rhodes, 2017), while being engaged civically and economically (Hintz, 2015; Trauger, 2017). It is a system that produces both flavorful and culturally appropriate food (Fontefrancesco, 2018), which is ecologically net positive (Hes \& du Plessis, 2015; Zari, 2018), and which aims at intergenerational (Hoover \& Mihesuah, 2019; Whyte, 2018) and interspecies justice (Dahlberg, 2009; Paxson, 2008).

This definition acknowledges that food systems should be approached holistically while being attuned to the nuances and circumstances of a place and its community. Solutions to food challenges should be derived by in situ producers and developed in the name of regeneration as inspired by nature's adaptation to place. Thus, Native people who have observed local adaptations and created agroecological systems should not only be included and consulted but also their know-how should be protected. Moreover, for a regenerative food system to grow and develop properly, it should involve its people civically and economically (with respect to food sovereignty and local food choices) while being embedded in cultural traditions that value culturally distinctive flavors, rituals, and ceremonies. A regenerative food system should not be resource-exhaustive or even carbonneutral; rather, it should have a net positive and regenerative impact, with the aim of achieving justice, of addressing the disproportionate burdens of environmental harm and lack of access to natural resources due to systemic injustices related to race, class, and gender (Guthman, 2014) for present and future generations of human and nonhuman species. Through the generation of this definition and the emergent baseline principles from literature, our work called for the integration of Life's Principles (LPs) and Traditional Ecological Knowledge (TEK) into a more comprehensive regenerative food systems framework.

\section{Life's Principles and Traditional Ecological Knowledge}

The emergent themes in the literature indicated the importance of nature's patterns to regeneration, meaning that food systems can take inspiration from nature's strategies such as multifunctional designs or circular systems with no waste. Thus, we turned to biomimicry's overarching characteristics, "Life's Principles" (LPs) (Baumeister, 2017). Small-scale producers whom we interviewed revealed that much of their knowledge about production, processing, and 
managing food derived from traditional wisdom, which constitutes knowledge meshed with practice and belief systems (Berkes et al., 2000). Traditional wisdom has different names but is commonly referred to as Traditional Ecological Knowledge (TEK). Subsequently, we describe and synthesize LPs and TEK and then contextualize and integrate them in relation to food systems.

\section{Biomimicry's Life's Principles}

As used in this paper, biomimicry refers to the strong form of biomimicry, which is conducive to ecological health, rather than the weak form that is mechanistic, and based on emulating form (Blok \& Gremmen, 2016). It is a design that is emulated from nature to enhance sustainability (Benyus, 1997). The nascent discipline looks to nature as inspiration to recreate strategies that are most adapted to life on planet Earth. Like TEK, biomimicry is an ancient practice. Humans have typically looked to nature for inspiration to design their world; Alaskan hunters will stalk seals emulating polar bears. Although borrowing from nature for inspiration has roots in Indigenous traditions, we refer here to the growing Western-based field of biomimicry, which has three main elements: emulate, ethos, and reconnect. Emulate is the process of learning from nature's strategies and adopting them to help solve sustainability challenges. Examples include self-cleaning paints that mimic the nanostructure of lotus leaves and the "Living Machine" that mimics a wetland to purify greywater (Laylin, 2010). Ethos is the philosophy that humans are part of nature and therefore should steward it. Reconnect is an invitation to be in nature and learn from it by nurturing our own relationship with the Earth (Baumeister, 2017). Learning from nature offers the potential for a different worldview of sustainability, based on understanding that nature is a "supra-system" of organizations and elements intersecting in complex relations, as well as a model, measure, and mentor (Benyus, 1997; Olaizola et al., 2020).

Biomimicry $3.8^{1}$ has developed the LPs framework over 20 years and several iterations. It consists of 26 guiding principles of patterns ubiquitous to and extrapolated from the natural world (see the diagram of 26 LPs in Figure B1, Appendix B). The principles serve as a valuable tool to establish sustainability baselines and move beyond them into regeneration, with the goal of supporting conditions conducive to life (Baumeister, 2017).

\section{What is Traditional Ecological Knowledge?}

I, El-Sayed, am still navigating the world of TEK, having not been raised in an Indigenous family. I have been drawn to Indigenous ways of knowing and the many storytellers in my life that have explained the world around us using science and spirituality. As an Egyptian/Italian, I felt compelled at a young age to connect with Indigenous elders in the Sinai, where I interned with Jabaliya elders, and unbeknownst to me was learning TEK through rituals and observing nature. I, Cloutier, have long felt drawn to TEK, learning about Indigenous farming practices like the Three Sisters, an Indigenous polyculture of corn, beans, and squash, as a young boy. I later connected with practices of TEK through Western perspectives like permaculture and natural building, followed by experiences with Celtic shamanism and ceremonial practices of connecting with and honoring the land and the intuitive wisdom Indigenous to all beings.

The term TEK became popularized in the 1980 s and is currently finding its way in academia, especially in relation to environmental issues such as adapting to climate change (Hosen et al., 2020). However, TEK refers to ancient practices (Berkes, 2018). TEKs are forms of knowledge that reflect diverse worldviews of traditional and Indigenous people. Different scholars have referred to them as "Indigenous knowledge" (I.K.), "traditional knowledge" (T.K.), and "Native science" (Berkes, 2018; Cajete, 2018; Whyte, 2013). TEK stems from Indigenous ways of knowing passed down by the oral tradition of elders and the cultural expression of arts, crafts, and ceremonies (Tsosie, 2017). It is a blend of science, spirituality, and ethics (McGregor, 2018), and includes the diversity of interactions among plants and animals, landforms, water-

\footnotetext{
${ }^{1}$ Biomimicry 3.8 is a B corporation founded in 1998 by Benyus and Baumeister that has pioneered the research, education, and application of biomimicry topics.
} 
courses, and other traits of the biophysical environment (Berkes, 1993; Frank, 2011). TEK has been called by Nelson and Shilling (2018) the "soul" of sustainability, highlighting Indigenous ethics long before Western science defined sustainability. It believes in reciprocity, nature-centering, valuing the dynamic relation of being attuned to the senses, and being responsive to the elements, as well as responsibility to future generations (Shilling, 2018). TEK shares similarities with the eco-feminist belief that humans are not separate from nature, that life is not about the domination of human over nature, or man over woman, but rather a co-existence based on caretaking, love, and reciprocity between species (Kimmerer, 2013; McGregor, 2018; Plumwood, 1993; Trauger, 2017; Whyte et al., 2016). It is a knowledge-practice-belief complex (Whyte, 2013; Berkes, 2000) with an emphasis on care and stewardship (Kimmerer, 2002), spanning generations (Nelson, 2017). (See the framework diagram of TEK in Appendix C, Figure C1.)

Unlike the industrialized relationship of food as a commodity, the TEK food relationship is sacred and founded on profound ethics of respect and gratitude for culture-land resources (Huambachano, 2018). Because of the sacredness of the relationship, many Indigenous communities, including many that were interviewed, have traditions of giving prayer at meals and sites visited. Food has not only sustenance value but is a reconnection to culture that can be expressed more accurately through food sovereignty and regenerative processes, rather than just a matter of sufficiency (Hoover \& Mihesuah, 2019). Such views of food are complicated, due to the impact that colonialism had on severing Indigenous communities from their culture and place and their sovereignty over their food. An example is the disenfranchisement by Native American boarding schools of Indigenous children from their foodways, which were supplanted by Western diets high in sugar and starch (Hoover \& Mihesuah, 2019). This paper will not explicitly address two key elements of TEK and food: food sovereignty and the importance of spirituality in Native cultures (Houde, 2007; Wilson, 2008). This paper focuses on areas of intersection with another ancient but reformulated discipline of nature inspiration.
Synthesis of LPs and TEK

LPs and TEK are strongly linked, given their emphasis on learning from nature's strategies and being attuned to the natural world, but we suggest that weaving them together would strengthen both. Many Indigenous communities describe how nature works as core to their understanding, which is the essence of biomimicry, and biomimicry describes understanding traditional knowledge as a form of connecting to and being inspired by nature. Kimmerer (2002) describes how both TEK and scientific ecological knowledge (SEK) rely on a systematic observation of nature, but that nature is subject in TEK and is object in SEK. Nelson describes how Native women have continued to be holders of ecological knowledge through their experience with plants and medicines, emphasizing their eco-feminist approach (Nelson, 2017). The Indian food sovereignty activist and scholar Vandana Shiva (2019) endorses care for plant diversity; Benyus (1997) discusses learning from Native insights, which often mimic nature, indicating that the discipline of biomimicry has roots in Indigenous knowledge systems. As the relationship is not explicitly correlated, this paper weaves them together, beginning with LPs and overlaying equivalent TEK principles gathered from publications, Indigenous scholarship, interviews, and workshops.

This paper focuses on the food system of arid regions. Because arid regions are so fragile, successful strategies and practices in these ecosystems may serve as models to emulate in a future when temperatures are rising and rainfall regimes shift. Although there are many similarities between the two disciplines, differences remain. Biomimicry, as defined in this paper, stems from Western epistemology, focusing on sustainability, while TEK is based on Indigenous sovereignty, justice, and the relationality of humans and nonhumans (Peña, 2019). Indigenous agroecological traditions existed before the arrival of more Western practices, some of which, such as permaculture, have even been influenced by indigenous knowledge but have not acknowledged it (Peña, 2019). This paper values each system but mainly highlights how the similarities between TEK and LPs can allow us to create a more regenerative food system. 


\section{Weaving LPs with TEK}

We began with 47 themes, coded in MAXQDA from both in vivo research and LPs and TEK principles. Themes were matched to the literature as well as interviews and workshop transcripts. The 47 themes included, for example, low technology, fermentation, microclimate, relationality, and taboo foods. We distilled themes into the LPs" "buckets" and matched them with equivalent TEK themes, and removed themes that were infrequent and thus insignificant. This enabled us to distill 13 LPs and their equivalent TEK principles. The principles were mapped onto a framework in the form of a spiral, showcasing the relationship between LPs and TEK and the equivalent practices related to arid regions. The principles lay out the LPs and their equivalent TEK principles, supplemented by examples of each within Indigenous food system practices.

\section{Regeneration Spiral}

The result of this iterative process was a regenerative food system spiral (Figure 2). It illustrates the parallels between LPs and TEK, beginning with the central circle and spiraling out in time-from one to two generations in the first tier and multiple generations in the second tier-and in complexity to the two outer layers. Each matching principle represents an LP (coded in green), and its equivalent TEK (coded in brown) based on the recurring themes that emerged most frequently from the data.

\section{Discussion}

A spiral, as explained by Louie Hena, a member of the Tesuque and Zuni Pueblos, shows how we are all related, as a pattern that is often repeated in nature-in galaxies, the eye of a hurricane, fingerprints, and seashells; among the traditional Pueblos the community started at the center of the circle and expanded in a spiral form (Hena, 2014). In nature many organisms take the spiral form and follow the golden angle, enabling growth without changing shape. Table 3 provides more details and descriptions for each principle, along with related practices. The spiral does not value one principle over another; rather, the principles occur over time. (The italicized words or phrases represent the
LPs and TEK principles.) The first seven principles form a system's foundation, ending this inner circle with the integrate development with growth/nested communities principle. The process leads to adaptations in the second spiral and the principle evolves over time through generations, as the system matures in the outer spiral.

Below is a detailed description of the principles. Each section contains (a) an explanation for each LP and the equivalent TEK principle; (b) an example to explain the LPs, using the saguaro cactus because of its cosmological tie to the Tohono O'odham Tribe, one of the tribes inhabiting the Sonoran desert where saguaros are found (Rea, 1997; Yetman et al., 2020) and association with survival strategies of arid regions; (c) one or more traditional food system practices stemming from community knowledge based on literature and observations and interviews involving producers and workshops in the arid Southwest (Figure 2 and Table 3).

More amazing perhaps than any aspect of its biology is Man's emotional involvement with the saguaro- - the saguaro is a "hero" among plants.

-S. Steenberg and C. Low, Ecology of the Saguaro II (quoted in Yetman et al., 2020)

\section{[Inner Spiral] Locally Attuned and Responsive/Place-Based Knowledge}

Being locally attuned and responsive (Baumeister, 2017) is the ability of living things to fit and integrate into the surrounding environment. Indigenous Knowledge is grounded in place-based knowledge, understanding the cycles specific to a place and eating what is adapted to the land and about the cycles specific to a place (Kealiikanakaoleohaililani \& Giardina, 2016).

An example of a highly adapted organism is the saguaro cactus, attuned to the desert by storing water in its pleated, expandable reservoir, protected from evaporation with thick waxy skin, and with spines that help it avoid predation as well cool it (Gibson \& Nobel, 1986). In arid regions, local attunement requires adapting to hot and dry summers, monsoonal summer periods, sparse rains in winter, and significant temperature differences 
from hot days to cold nights. Similarly, the Tohono O'odham of the Sonoran Desert have mastered local attunement and place-based knowledge by using multiple growing seasons for wheat, greens, and agave, diversifying and foraging for food, such as saguaro and velvet mesquite, and rabbit hunting and fishing (Rea, 1997). A Salt River Pima Indian community member stated that in the past they managed ridges near the Verde river with agave groves, both stabilizing the soil and providing food.

\section{[Inner Spiral] Cultivate Cooperative Relationships/Relationality}

Nature thrives on cooperative relations; it nurtures mutualisms and symbiotic relationships (Baumeister, 2017). To nurture place, Indigenous communities strive to build strong bonds with both the place and among their people, creating strong relations (LaDuke, 2016). Indigenous people will often introduce themselves by their name and their clan name, giving respect to both the ancestors as well as the land they have come from. A regenerative food system also is based on a nurturing relationship whose result is not limited to feeding humans but may provide a habitat for pollinators or create favorable soil biology by fostering beneficial soil microbes and fungi. In TEK, everything is relational, relations with people, with the cosmos, plants, and animals: it is a responsibility to the earth (Twila Cassadore, Wisdom of Indigenous Foodways workshop; see Appendix D). An interview with a Tohono O'odham woman featured traditional songs about freshly harvested saguaro fruit she knew as a little girl; plants and even seeds are seen as related. A Mohawk/Anishinabek instructor began each session with a prayer thanking the elements, the plants, animals, the food, and ourselves for our presence at each activity, as giving thanks also honors relationships (ISCDC Workshop, 2019: Appendix D).

\section{[Inner Spiral] Leveraging Cyclic Processes/ Cycles of the Earth}

Nature leverages cyclic processes such as day and night, tides, and seasons (Benyus, 1997). Understanding place is about understanding its physical conditions and the natural cycles of Earth that form a place, and how to leverage them. Indigenous communities have historically leveraged cycles via rituals, ceremonies, and festivals (Whyte et al., 2016). The saguaro leverages the seasonal monsoonal rains that enable it to survive its arid climate. The Tekna herders, members of an Arab-Berber tribe in southern Morocco, leverage the seasonal ephemeral plants found after rains by moving several hundred kilometers to where the plans are, since they provide a good diet for animals; but they also diversify by buying forage in other periods, therefore leveraging cycles over a year to ensure a diverse diet for their herds (Blanco et al., 2017). The Zuni of New Mexico traditionally managed water before the monsoonal seasons by creating check dams, small dykes, and Zuni bowls to slow water as it came down valleys (Lancaster, 2013; Nabhan, 2013). In the past, work parties would be organized and gather annually to manage the mountains and valleys, preparing them for the next period of rains to ensure that the cycles had been leveraged to optimize water retention (ISCDC Workshop, 2019: Appendix D).

\section{[Inner Spiral] Feedback Loops/Reciprocity}

Leveraging cycles are dependent upon a larger feedback system in nature, with negative and positive feedback allowing for self-regulation (Benyus, 1997), creating a form of reciprocity. During the summer, the saguaro's white flower blooms at night and sends a signal to migrating lesser longnosed bats, which creates positive feedback. The bats are invited to eat nectar, pollen, and fruit, aiding the cactus in pollination (Yetman et al., 2020). Indigenous communities also have cycles of regulation in the form of reciprocal caretaking (Kimmerer, 2013). Reciprocity is also referred to as "all our relations" to living things, when prayers are whispered across generations to all "our relatives" (LaDuke, 2016), stressing the importance of caretaking. Honorable harvest is another instance of reciprocity (Kimmerer, 2018). At the beginning of harvest, permission is asked to take, and take only what is needed is taken, praise is given, and a gift reciprocated, such as burning tobacco (Kimmerer, 2018). A Pueblo artist and permaculture designer in New Mexico emphasizes the importance of creating micro-environments in her home to feed 
herself and her family and to create opportunities for other life to thrive in the harsh desert environment, such as creating a rock habitat that enables small pockets of shelter and life to exist (Interviewee F13, 2019).

\section{[Inner Spiral] Resource and Energy Efficiency and Cycling/Management Systems}

A tight feedback loop also includes resource efficiency, the ability to manage resources and energy conservatively and efficiently (Baumeister, 2017). This is also known as resource management systems in Indigenous communities (Berkes, 2018). The structure of a saguaro has evolved systematically to cool the plant by creating microconvections around each spine, as well as to expand and contract to store water (Phillips \& Wentworth, 1999). Dryland farming is an example of the management systems practiced by the Hopi of Arizona. Dryland farming uses minimal water, mostly what falls during monsoons, to grow highly adapted corn seeds cultivated up to a foot beneath the soil (Michael Johnson, Wisdom of Indigenous Foodways workshop, Appendix D). Other resource-efficient farming practices include using compost and mulch to retain moisture and nutrients in the soil. The Western Apache of White River grow crops needed on the reservation by managing the cycling of nutrients and enriching the soil with mycelia as well as compost mixtures at different intervals in the growing season. While these are not traditional practices, the Western Apache recognize that cycling nutrients from local resources is important to enable the soil to regenerate and enable crop diversity (Interviewee F2, 2019).

\section{[Inner Spiral] Low Energy Processes/ Preservation and Conservation}

Another level of resource efficiency in the natural world is the principle of low-energy processes (Baumeister, 2017), which are expressed as preservation and conservation practices by Indigenous communities. An example from nature is photosynthesis, where the process requires sunlight as a source of energy to produce sugars and enable a plant to produce sugars. The saguaro cactus has a large surface area to facilitate the process and leverages capillary action to move water up the plant, and is composed of a tough composite waxy cuticle to reduce water loss. Emulating from this strategy would mean using passive energy sources such as the sun to power food systems. In Indigenous arid communities, or where food harvest is limited, preservation and conservation practices are crucial at certain periods of the year. Drying and fermenting foods are especially important. In Egypt, vegetables such as okra and tomatoes are sun-dried, while dairy and grains are fermented and dried to be used throughout the year. In the summer, the Tohono O'odham of the Sonoran Desert organize foraging parties to gather saguaro fruit, which is processed into a thick syrup, a jam, and a fermented ceremonial rain-making wine to preserve it due to its short fruiting season.

\section{[Inner Spiral] Integrate Development with Growth/Nested Communities}

A food system needs time to develop and, in the natural world, development is integrated with growth; similarly, traditional communities have nested structures (Baumeister, 2017). For instance, saguaro needs many years to grow its columnar structure to 3-4 meters, before any branch is formed. The cells then differentiate to begin a branch by creating a small bud (Pierson et al., 2012). Life does not happen from the top down, but rather from the bottom up in small nested units, such as cells that make tissues that make organs. Many Indigenous communities developed in modular nested units of small bands that then organized into larger, more complex units. The Navajo or Diné people organized themselves in complex food systems that came together around important food activities, forming nested communities. They organized matrilineal clans that often organized around food-related activities; some clans even named themselves based on foods, such as the Naadaa Diné, or Corn People Clan. They came together to plow, plant, weed, and harvest, as well as prepare certain foods collectively, such as making ground-baked corn cake (Eldridge et al., 2014). Native Southern Californians such as the Cahuilla also established complex clans and families, creating nested communities around pruning oaks for acorn production, sowing, weeding, and burning meadowlands to produce grassy pastures that in turn supported wild 
animals (Hoover \& Mihesuah, 2019). This sustainable management of lands maintained a balance to control wildfires, in comparison to today's lack of effective management (Hoover \& Mihesuah, 2019). The Indigenous Siwans of Egypt have created complex agroforestry systems, developed from small units of grove gardens with polycultures of palm trees, figs, and apricots with an understory of vegetables in a very arid environment.

\section{[Second Spiral] Adapt to Changing Conditions/ Resilient Co-inhabitation}

The principle adapted to changing conditions is the ability to continually respond to changes in the local conditions. Indigenous communities have embodied this as resilient co-inhabitation. The saguaro cactus has adapted to the Sonoran Desert and the harsh climatic conditions, using small seeds that are drought resistant and multiple strategies to capture and store water, self-cool, and defend itself from predators. However, to ensure successful growth, a juvenile saguaro can only be established after two consecutive years of summer monsoonal rains (Pierson et al., 2012). This resilient co-babitation has allowed traditional communities to adapt to environmental demands (Peña, 2019). Through trial and error, Native communities have selected the most drought-tolerant crops, creating living seed banks (Linda Black Elk, Intertribal Food Summit, Appendix D; Interviewee F13, 2019), and acquired practices such as allowing certain areas of a forest to burn.

\section{[Second Spiral] Incorporate Diversity/Diversification}

For effective adaptation, it is important to incorporate diversity. Genetic diversity ensures that organisms can withstand disturbance. In food systems, diversity is supported through the cultivation of perennial crops and diverse cover crops with intercropping rotation (Crews \& Rumsey, 2017). The saguaro's diverse strategies for dealing with aridity have enabled its survival. Indigenous communities value diversification in various aspects of food production, from growing polycultures to growing different crops in different seasons, as well as tending wild plants (Nabhan, 1997). Traditional communities in the Americas have grown the Three
Sisters of corn, beans, and squash, maintaining the diverse varieties within these three groups (Melissa Nelson, Intertribal Food Summit, Appendix D; Interviewee F4, 2019). In the Sinai, the Jabaliya Bedouins grow orchards with apples, apricots, almonds, quince, figs, pomegranate, and mulberries (Gilbert, 2011). Jabaliya maintain desert-adapted orchards of olives, apricots, almonds, and other fruits, while growing hardy grains and raising herds of goats and sheep that feed on wild shrubs, thus ensuring they are diversifying their sources of food.

\section{[Second Spiral] Self-RenewallRebirth and Renewal}

Within this diversification is self-renewal or rebirth or replenishment, which can be in the form of new cells or new tissues of an organism (Baumeister, 2017), or a ceremonial rebirth. For example, when the Gila woodpecker punctures the trunk of a saguaro, the plant quickly heals itself and creates a hard, watertight scab that can even become a habitat for other organisms (Phillips \& Wentworth, 1999). Many Indigenous communities are highly attuned to renewal; for example, herders often move from one grassland to another to ensure that grasses have sufficient time to self-renew. Indigenous communities often conduct rituals such as smoke ceremonies to create an experience of rebirth (Sunny Dole, Indigenous Innovation Workshop, Appendix D; Frank, 2011; Peña, 2019). A Kiowa Chief shared that Hopi rituals of rain and fertility are songs to the spirit of the Corn Mother; the Diné perform Sun Dances as a form of summer purification, with the hope that these prayers and songs will invite new life (Interviewee C1, 2019; Frank, 2011).

\section{[Second Spiral] Embody Resilience/Survivance}

Such strategies lead to resilience to disturbances; variation, redundancy, and decentralization are mechanisms that ensure resilience in living things (Baumeister, 2017). Part of the saguaro's resilience strategy is its defenses against predation with its many spikes, diverse water capture mechanisms, and self-cooling strategy. In TEK, the ability to provide resilience in communities and their endurance despite domination has been described by Vizenor (1994) as survivance, a sense of active 
presence and continuance through living and recounting Native stories (Whyte, 2017). Essentially, that despite concerted efforts to eradicate Indigenous communities throughout history, they continue to survive and refashion their culture through their oral traditions. For example, it is customary among the Tohono O'odham for children to follow the grandmothers on nature walks, to collect wild plants or catch rabbits, and during these walks many songs and stories are told. In some cases, these walks are refashioned as workshops where unrelated children might follow a grandmother, thus actively continuing the passing on and presence of their traditions to adapt to a modern age (Interviewee F13, 2019).

\section{[Outer Spiral] Replicate Strategies that Work/Generating, Validating and Interpreting}

The genetic makeup of organisms is constantly replicated, where successful strategies that work and enable the organism to survive are passed to the next generation (Baumeister, 2017). Communities generate, validate, and interpret information that they have observed in their surroundings. As an example, agro-biomimicry is the TEK generation of agricultural systems that mimic the environment, including wild plants, to create ecosystems. This is what has enabled the saguaro species to persist: gene mutations that enabled the species to adapt and evolve through millennia despite dramatic changes in climate (Yetman et al., 2020). Generating, validating, and interpreting knowledge enables the passing on of persistent strategies such as the growing of perennial trees that complement each other, utilizing annual polycultures, growing soils that are not tilled, and integrating animals in the rotation to fertilize the soil and cut through it with their hooves (Elevitch et al., 2018; Peña, 2019). These strategies have persisted, especially as placebased knowledge, with the continual understanding of rain patterns, soils, irrigation, growing perennials, and maintaining foods through preservation techniques (Ford \& Swentzell, 2015).

\section{[Outer Spiral] Evolve to Survivel Intergenerational Learning}

For a regenerative system to persist, it needs to evolve over generations, continually embodying information to enable it to evolve to survive; it also needs to pass on the knowledge intergenerationally in communities. Adaptation through natural selection has enabled the Cacti family to evolve into many niches. The saguaro evolved its mechanism of obtaining carbon dioxide from the typical photosynthesis process to the specialized crassulacean acid metabolism (CAM) mechanism, enabling the plant to gather sunlight by day without losing water, and then use water to produce its sugars by night (Gibson \& Nobel, 1986; Yetman et al., 2020). The intergenerational learning of Indigenous people takes place through songs and poetry passed down across generations. Native activist Winona LaDuke asserts that a viable Indigenous paradigm for intergenerational learning is to think and act in terms of seven generations: three in the past, the present, and three in the future (LaDuke, 2016). Intergenerational learning is exemplified by the work of a Tohono O'odham Gila River farmer and her daughters, who take the lead in educating the next generation about the tepary beans they grow today that originated with her parents (Interviewee F5, 2019). An Indigenous permaculture course led by the Traditional Native American Farmers Association (TNAFA) is a modern way of passing the knowledge of the elders to the younger generations.

\section{Conclusion}

In conceptualizing a regenerative food system, biomimicry's ubiquitous LPs were woven with TEK principles, and 13 principles were identified (numbered below) and contextualized to arid regions. The principles highlight the importance of (1) place-based knowledge and a local attunement that is established through strong (2) cooperative relations, not just with people, but with all of creation, that in turn supports our foods. Therefore, relations must be reciprocal with nonhumans (Kimmerer, 2013) and the cosmos (Wilson, 2008). Reciprocity involves creating a (3) feedback loop, a cycle of care (Kealiikanakaoleohaililani \& Giardina, 2016) and gratitude, which could come in the form of a gift or an offering. Such local attunement is achieved by understanding (4) nature's cycles and leveraging them by knowing when to grow in tune with the seasons and cycles. With this stewardship 
toward the earth, there is also a sense of (5) frugal and resourceful management, and establishing how to utilize resources and energy effectively and

(6) use low-energy processes that preserve and conserve foods.

In this conceptual framework, once a regenerative food system is established, (7) growth happens slowly from the bottom up, as complex communities are nested within and benefit one another while developing together to create a complex and interdependent society. In turn, communities grow to become well-adapted ecosystems, known in TEK as (8) resilient co-habitation because they have (9) diversified their diet, their growth patterns, and their crops, and incorporate patterns of (10) self-renewal through ritual and ceremony. This ultimately enables a system to be resilient due to community (11) survivance, the ability to persist, with food traditions passed through stories, songs and rituals. As a community persists, it evolves and passes this knowledge across generations, adapted to present situations with a forward outlook. In Indigenous traditions, learning and (12) replicating strategies that work and validating them ultimately (13) evolves across seven generations (Kealiikanakaoleohaililani \& Giardina, 2016; Whyte et al., 2016). A regenerative food system thus honors small-scale and traditional practices while being grounded in teachings of the past, realities of the present, and ways to be more in tune for the future.

We have provided a path demonstrating how TEK and LPs can weave together and create a definition and a conceptual framework for a regenerative food system, guided by community practices from food systems in arid regions, in the spirit of Albert Marshall's Two-Eyed Seeing: learning "to see from one eye with the best in our Indigenous ways of knowing, and from the other eye with the best in the Western (or mainstream) ways of knowing $\ldots$ and learn to use both these eyes together, for the benefit of all" (Marshall \& Bartlett, 2010, slide 12). It is imperative to move beyond both the industrial food system and the narratives of sustainable solutions, which claim merely to improve some of the unintended consequences of the industrial food system. These two systems have not taken into consideration small- scale producers and their traditional and Indigenous processes. However, neither sustainable nor regenerative food systems have been realized on a larger scale. The need remains to create a more equitable system across generations and species to ensure a positive impact of food production on our environment and our communities, which the regenerative food system is beginning to fill.

Limitations of this study include using a feminist lens that acknowledges positionality; it is not common practice in academia since this narrative is viewed as subjective. It is, however, an attempt at being more transparent. Haraway (1988) states that knowledge in feminist scholarship is situated, and thus it is important to consider the account's embeddedness (Gottschlich et al., 2017). For us (ElSayed and Cloutier), our human journey, thus far, and subjectivity of the experience(s) are inherent within and to the narrative. Another limitation has been using emergent grounded theory methods, and we acknowledge having not reached saturation (Tie et al., 2019). Our sample was relatively small, as we were trying to interview people across the food chain, making the research a work in progress. As with most research, it needs further validation; we look for insights from Indigenous communities, as well as possible new principles that may arise.

In weaving together these two disciplines, we aim to bridge the gap between them, due to their strong correlations. However, many questions remain unanswered, such as, How can nonIndigenous communities embody such principles, and what would the benefits be? How do these principles translate into strategies and policies? Can we create truly regenerative systems that have a net positive impact on nature and their communities? In the meantime, we, the authors, believe that it is possible to weave together these two disciplines, and offer this research as a seed for future efforts to explore.

\section{Acknowledgments}

The authors wish to acknowledge the small-scale and traditional producers who accepted interviews and field visits, The Biomimicry Center, Ahmed Barakat for the design of graphics, and Dr. Melissa Nelson for valuable feedback. 


\section{References}

Ackerly, B., \& True, J. (2010). Doing feminist research in political and social science. Red Globe Press.

Adamson, J., Gleason, W. A., \& Pellow, D. N. (Eds.). (2016). Keywords for environmental studies. New York University Press.

Ahmed, S., \& Asraf, R. M. (2018). The Workshop as a Qualitative Research Approach: Lessons Learnt from a "Critical Thinking Through Writing" Workshop. The Turkish Online Journal of Design, Art and Communication, Special edition, 1504-1510.

Allen, P., \& Sachs, C. (1991). The social side of sustainability: Class, gender and race. Science as Culture, 2(4), 569-590. https://doi.org/10.1080/09505439109526328

Altieri, M. A. (1995). Biodiversity and biocontrol: Lessons from insect pest management. In J. H. Andrews \& I. C. Tommerup (Eds.), Advances in plant pathology, Vol. 11 (pp. 191-209). Academic Press. https://doi.org/10.1016/S0736-4539(06)80012-7

Altieri, M. A. (2002). Agroecology: The science of natural resource management for poor farmers in marginal environments. Agriculture, Ecosystems \& Environment, 93(1-3), 1-24. https://doi.org/10.1016/S0167-8809(02)00085-3

Altieri, M. A., Funes-Monzote, F. R., \& Petersen, P. (2011). Agroecologically efficient agricultural systems for smallholder farmers: Contributions to food sovereignty. Agronomy for Sustainable Development, 32(1), 1-13. https://doi.org/10.1007/s13593-011-0065-6

Baret, P. V. (2018). Acceptance of innovation and pathways to transition towards more sustainable food systems. Potato Research, 60(3-4), 383-388. https://doi.org/10.1007/s11540-018-9384-1

Baumeister, D. (2017). Biomimicry resource handbook: A seed bank of best practices. Biomimicry 3.8 .

Bausch, J. C., Eakin, H., Smith-Heisters, S., York, A. M., White, D. D., Rubiños, C., \& Aggarwal, R. M. (2015). Development pathways at the agriculture-urban interface: The case of Central Arizona. Agriculture and Human V alues, 32(4), 743-759. https://doi.org/10.1007/s10460-015-9589-8

Benyus, J. M. (1997). Biomimicry: Innovation inspired by nature. William Morrow.

Berkes, F. (1993). Traditional ecological knowledge in perspective. In Inglis T. J. (Ed.), Traditional ecological knowledge: Concepts and cases (pp. 1-10). International Development Research Centre.

Berkes, F. (2018). Sacred ecology (4th ed.). Routledge.

Berkes, F., Colding, J., \& Folke, C. (2000). Rediscovery of traditional ecological knowledge as adaptive management. Ecological Applications, 10(5), 1251-1262. https://doi.org/10.1890/1051-0761(2000)010[1251:ROTEKA]2.0.CO;2

Beus, C. E., \& Dunlap, R. E. (1990). Conventional versus alternative agriculture: The paradigmatic roots of the debate. Rural Sociology, 55(4), 590-606. https://doi.org/10.1111/j.1549-0831.1990.tb00699.x

Birkeland, J. (2008). Positive development: From vicious circles to virtuous cycles through build environment design. Routledge.

Blanco, J., Michon, G., \& Carriere, S. M. (2017). Natural ecosystem mimicry in traditional dryland agroecosystems: Insights from an empirical and holistic approach. Journal of Environmental Management, 204(Part 1), 111-122. https://doi.org/10.1016/j.jenvman.2017.08.030

Blok, V., \& Gremmen, B. (2016). Ecological innovation: Biomimicry as a new way of thinking and acting ecologically. Journal of Agricultural and Environmental Ethics, 29(2), 203-217. https://doi.org/10.1007/s10806-015-9596-1

Cajete, G. (2018). Native science and sustaining Indigenous communities. In M. K. Nelson \& D. Shilling (Eds.), Traditional ecological knowledge: Learning from Indigenous practices for environmental sustainability (pp. 15-26). Cambridge University Press. https://doi.org/10.1017/9781108552998.003

Carlisle, L. (2016). Making heritage: The case of Black Beluga agriculture on the Northern Great Plains. Annals of the American Association of Geographers, 106(1), 130-144. https://doi.org/10.1080/00045608.2015.1086629

Charmaz, K., \& Belgrave, L. L. (2019). Thinking about data with grounded theory. Qualitative Inquiry, 25 (8), $743-753$. https://doi.org/10.1177/1077800418809455

Coté, C. (2019). hishuk'ish tsawalk-Everything is one: Revitalizing place-based Indigenous food systems through the enactment of food sovereignty. Journal of Agriculture, Food Systems, and Community Development, 9(Supplement 1), 37-48. https://doi.org/10.5304/jafscd.2019.09A.003

Crews, T. E., \& Rumsey, B. E. (2017). What agriculture can learn from Native ecosystems in building soil organic matter: A review. Sustainability, 9(4), 578. https://doi.org/10.3390/su9040578 
Dahlberg, K. A. (1993). Regenerative food systems: Broadening the scope and agenda of sustainability. In P. Allen (Ed.), Food for the future: Conditions and contradictions of sustainability (pp. 75-102). John Wiley \& Sons.

Dahlberg, K. A. (1994). A transition from agriculture to regenerative food systems. Futures, 26(2), 170-179. https://doi.org/10.1016/0016-3287(94)90106-6

Dahlberg, K. A. (2009). Regenerative food systems. In R. J. Hudson (Ed.), Management of agricultural, forestry and fisheries enterprises. Encyclopedia of life support systems (EOLSS), Vol. 2, 1-18. UNESCO/EOLSS Publishers. http://www.eolss.net/Sample-Chapters/C10/E5-15-07-05.pdf

DeLind, L. B. (2011). Are local food and the local food movement taking us where we want to go? Or are we hitching our wagons to the wrong stars? Agriculture and Human Values, 28(2), 273-283. https://doi.org/10.1007/s10460-010-9263-0

Du Plessis, C., \& Brandon, P. (2015). An ecological worldview as basis for a regenerative sustainability paradigm for the built environment. Journal of Cleaner Production, 109, 53-61. https://doi.org/10.1016/i.jclepro.2014.09.098

Dunn, R. (2017). Never out of season: How having the food we want when we want it threatens our food supply and our future. Little, Brown.

Eakin, H., Connors, J. P., Wharton, C., Bertmann, F., Xiong, A., \& Stoltzfus, J. (2017). Identifying attributes of food system sustainability: Emerging themes and consensus. Agriculture and Human Values, 34(3), 757-773. https://doi.org/10.1007/s10460-016-9754-8

Edelman, M., Weis, T., Baviskar, A., Borras Jr, S., Holt-Giménez, E., Kandiyoti, D., \& Wolford, W. (2014). Introduction: Critical perspectives on food sovereignty. The Journal of Peasant Studies, 41(6,), 911-931. https://doi.org/10.1080/03066150.2014.963568

Eldridge, D., McKenzie, J., Jackson, R., Denny, A., Yazzie, R., Crotty, A. K., \& Curley, C. (2014). Diné food sovereignty : A report on the Navajo Nation food system and the case to rebuild a self-sufficient food system for the Diné People. Diné College, Diné Policy Institute. https://www.dinecollege.edu/wp-content/uploads/2018/04/dpi-food-sovereignty-report.pdf

Elevitch, C. R., Mazaroli, D. N., \& Ragone, D. (2018). Agroforestry standards for regenerative agriculture. Sustainability, 10(9), 3337. https://doi.org/10.3390/su10093337

Ericksen, P. J. (2008). Conceptualizing food systems for global environmental change research. Global Environmental Change, 18(1), 234-245. https://doi.org/10.1016/i.gloenvcha.2007.09.002

Fontefrancesco, M. F. (2018). The Slow Food model : A road for small-scale productions in a globalised market. International Journal of Agricultural Management and Development, 8(1), 17-23. https://doi.org/10.22004/ag.econ.292517

Food and Agriculture Organization of the United Nations [FAO]. (2015, July 22). Food loss and waste facts. Food and Agriculture Organization of the United Nations. http://www.fao.org/resources/infographics/infographics-details/en/c/317265/

Ford, R. I., \& Swentzell, R. (2015) Precontact agriculture in northern New Mexico. In S. E. Ingram \& R. C. Hunt (Eds.), Traditional arid lands agriculture: Understanding the past for the future (pp. 330-357). University of Arizona Press. http://www.jstor.org/stable/j.ctt183pdbg.14

Frank, L. E. (2011). The discourse and practice of Native American cuisine: Native American chefs and Native American cooks in contemporary Southwest kitchens [Doctoral dissertation, University of New Mexico]. https://digitalrepository.unm.edu/anth etds/24

Gibbons, L. V., Cloutier, S. A., Coseo, P. J., \& Barakat, A. (2018). Regenerative development as an integrative paradigm and methodology for landscape sustainability. Sustainability, 10(6), 1910. https://doi.org/10.3390/su10061910

Gibson, A. C., \& Nobel, P. S. (1986). The cactus primer. Harvard University Press.

Gilbert, H. (2011). 'This is not our life, it's just a copy of other people's': Bedu and the price of 'development' in South Sinai. Nomadic Peoples, 15(2), 7-32. https://doi.org/10.3167/np.2011.150203

Glennie, C., \& Alkon, A. H. (2017). Food justice: Cultivating the field. Environmental Research Letters, 13(7), Article 073003. https://doi.org/10.1088/1748-9326/aac4b2

Gliessman, S. R. (2007). Agroecology: The ecology of sustainable food (2nd Ed.). CRC Press. https://doi.org/10.1201/b17420 
Gottschlich, D., Mölders, T., \& Padmanbhan, M. (2017). Introduction to the symposium on feminist perspectives on human-nature relations. Agriculture and Human Values, 34(4), 933-940. https://doi.org/10.1007/s10460-016-9762-8

Guthman, J. (2014). Doing justice to bodies? Reflections on food justice, race, and biology. Antipode, 46(5), $1153-1171$. https://doi.org/10.1111/anti.1017

Haraway, D. (1988). Situated knowledges: The science question in feminism and the privilege of partial perspective. Feminist Studies, 14(3), 575-599. https://doi.org/10.2307/3178066

Haraway, D. (2008). When species meet. University of Minnesota Press.

Harcourt, W. (2017). Gender and sustainable livelihoods: Linking gendered experiences of environment, community and self. Agriculture and Human Values, 34(4), 1007-1019. https://doi.org/10.1007/s10460-016-9757-5

Hena, L. (2014). The spiral [Audio lecture on Soundcloud platform]. Bioneers. https://soundcloud.com/bioneers/louie-hena-the-spiral

Hes, D., \& du Plessis, C. (2015). Designing for hope: Pathways to regenerative sustainability. Routledge.

Hintz, C. M. H. (2015). 'Soil in my blood': Women farmers, transformative learning, and regenerative agriculture [Doctoral dissertation, Prescott College]. ProQuest dissertations and theses No. 3706204.

Holmgren, D. (2007). Essence of permaculture. Holmgren Design. https://store.holmgren.com.au/product/essence-of-permaculture-ebook

Hoover, E., \& Mihesuah, D. A. (2019). Introduction. In D. A. Mihesuah \& E. Hoover (Eds.), Indigenous food sovereignty in the United States: Restoring cultural knowledge, protecting environments, and regaining health (pp. 3-25). University of Oklahoma Press.

Hosen, N., Nakamura, H., \& Hamzah, A. (2020). Adaptation to climate change: Does traditional ecological knowledge hold the key? Sustainability, 12(2), Article 676. https://doi.org/10.3390/su12020676

Houde, N. (2007). The six faces of traditional ecological knowledge: Challenges and opportunities for Canadian comanagement arrangements. Ecology and Society, 12(2), Article 34. http://www.ecologyandsociety.org/vol12/iss2/art34/

Huambachano, M. (2018). Enacting food sovereignty in Aotearoa New Zealand and Peru: revitalizing Indigenous knowledge, food practices and ecological philosophies. Agroecology and Sustainable Food Systems, 42(9), $1003-1028$. https://doi.org/10.1080/21683565.2018.1468380

Ilmonen, K. (2020). Feminist storytelling and narratives of intersectionality. Signs: Journal of Women in Culture and Society, 45(2), 347-371. https://doi.org/10.1086/704989

Jackson, W. (2010). Consulting the genius of the place: An ecological approach to a new agriculture. Counterpoint.

Jackson, W., \& Jensen, R. (2018). Transforming human life on our home planet, perennially. The Ecological Citizen, 2(1), 43-46. https://www.ecologicalcitizen.net/pdfs/v02n1-08.pdf

Kealiikanakaoleohaililani, K., \& Giardina, C. P. (2016). Embracing the sacred: an indigenous framework for tomorrow's sustainability science. Sustainability Science, 11(1), 57-67. https://doi.org/10.1007/s11625-015-0343-3

Kimmerer, R. W. (2013). Braiding sweetgrass: Indigenous wisdom, scientific knowledge, and the teachings of plants. Milkweed.

Kimmerer, R. W. (2018). Mishkos Kenomagwen, the lessons of grass: Restoring reciprocity with the good green earth. In M. K. Nelson \& D. Shilling (Eds.), Traditional ecological knowledge: Learning from Indigenous practices for environmental sustainability (pp. 27-53). Cambridge University Press.

Kimmerer, R. W. (2002). Weaving traditional ecological knowledge into biological education: A call to action. BioScience, 52(5), 432-438. Retrieved from https://academic.oup.com/bioscience/article-abstract/52/5/432/236145

Kloppenburg, J., Lezberg, S., De Master, K., Stevenson, G. W., \& Hendrickson, J. (2000). Tasting food, tasting sustainability: Defining the attributes of an alternative food system with competent, ordinary people. Human Organization, 59(2), 177-186. https://doi.org/10.17730/humo.59.2.8681677127123543

LaCanne, C. E., \& Lundgren, J. G. (2018). Regenerative agriculture: Merging farming and natural resource conservation profitably. PeerJ, 6, Article e4428. https://doi.org/10.7717/peerj.4428

LaDuke, W. (2016). All our relations: Native struggles for land and life. Haymarket Books. 
Lancaster, B. (2013). Rainwater harvesting for drylands, vol. 1: Guiding principles to welcome rain into your life and landscape (2nd ed.). Rainsource Press.

Laylin, T. (2010, June 8). The Living Machine: An ecological approach to poo. The Ecologist [environmental news website]. https://theecologist.org/2010/jun/08/living-machine-ecological-approach-poo

Lerman, E. (2018). Dramaturgy as litany. In R. Bowditch, J. Casazza, \& A. Thornton (Eds.), Physical dramaturgy: Perspectives from the field (pp. 74-77). Routledge. https://doi.org/10.4324/9781315544861-7

Leifeld, J. (2012). How sustainable is organic farming? Agriculture, Ecosystems \& Environment, 150, $121-122$. https://doi.org/10.1016/j.agee.2012.01.020

Lincoln, Y. S., Guba, E. G., \& Pilotta, J. J. (1985). Naturalistic inquiry. SAGE. https://doi.org/10.1016/0147-1767(85)90062-8

Mang, P., \& Reed, B. (2012). Designing from place: A regenerative framework and methodology. Building Research \& Information, 40(1), 23-38. https://doi.org/10.1080/09613218.2012.621341

Mang, P., \& Reed, B. (2015). The nature of positive. Building Research \& Information, 43(1), 7-10. https://doi.org/10.1080/09613218.2014.911565

Marshall, A., \& Bartlett, C. (2010, February 4). Traditional knowledge meets Western knowledge. Two-Eyed Seeing: An old-new way of bringing together different perspectives [Learning seminar presentation]. Government of Nova Scotia, Office of Aboriginal Affairs. http://www.integrativescience.ca/uploads/articles/2010February-Bartlett-Marshall-IntegrativeScience-Two-Eyed-Seeing-Mi'kmaq-Western-knowledge-learning.pdf

McGregor, J. (2018). Toward a philosophical understanding of TEK and ecofeminism. In M. K. Nelson \& D. Shilling (Eds.), Traditional ecological knowledge: Learning from Indigenous methods for environmental sustainability (pp. 109-128). Cambridge University Press.

Merchant, C. (1996). Earthcare: Women and the environment. Routledge.

Mollison, B. (1990). Permaculture: A practical guide for a susstainable future. Island Press.

Nabhan, G. P. (1997). Cultures of habitat: On nature, culture and story. Counterpoint.

Nabhan, G. P. (2013). Growing food in a hotter, drier land: Lessons from desert farmers on adapting to climate uncertainty. Chelsea Green Publishing.

Nelson, M. K. (2017). Conclusion: Back in our tracks_Embodying kinship as if the future mattered. In M. K. Nelson \& D. Shilling (Eds.), Traditional ecological knowledge: Learning from Indigenous methods for environmental sustainability (pp. 250266). Cambridge University Press.

Nyéléni. (2007). Declaration of the Forum for Food Sovereignty, Nyéléni 2007. http://nyeleni.org/spip.php?article290

Olaizola, E., Morales-Sánchez, R., \& Eguiguren Huerta, M. (2020). Biomimetic organisations: A management model that learns from nature. Sustainability, 12(6), 2329. https://doi.org/10.3390/su12062329

Ørngreen, R., \& Levinsen, K. (2017). Workshops as a research methodology. Electronic Journal of e-Learning, 15(1), 70-81. https://eric.ed.gov/?id=EJ1140102

Patel, R. (2012). Stuffed and starved: The hidden battle for the world food system (rev. ed.). Melville House.

Patel, R., \& Moore, J. W. (2017). A bistory of the world in seven cheap things: A guide to capitalism, nature, and the future of the planet. University of California Press.

Paxson, H. (2008). Post-Pasteurian cultures: The microbiopolitics of raw-milk cheese in the United States. Cultural Anthropology, 23(1), 15-47. https://doi.org/10.1111/j.1548-1360.2008.00002.x

Peña, D. G. (2019). On intimacy with soils: Indigenous agroecology and biodynamics. In D. A. Mihesuah \& E. Hoover (Eds.), Indigenous food sovereignty in the United States: Restoring cultural knowledge, protecting environments, and regaining health (pp. 276-299). University of Oklahoma Press.

Phillips, S. J., \& Wentworth, P. (1999). A natural history of the Sonoran Desert. University of California Press/ArizonaSonora Desert Museum Press.

Pierson, E. A., Turner, R. M., \& Betancourt, J. L. (2012). Regional demographic trends from long-term studies of saguaro (Carnegiea gigantea) across the northern Sonoran Desert. Journal of Arid Environments, 88, 57-69. https://doi.org/10.1016/i.jaridenv.2012.08.008 
Plumwood, V. (1993). Feminism and the mastery of nature. Routledge. https://takku.net/mediagallery/mediaobjects/orig/f/f val-plumwood-feminism-and-the-mastery-of-nature-pdf.pdf

Portman, A. (2018). Food sovereignty and gender justice. Journal of Agricultural and Environmental Ethics, 31(4), 455-466. https://doi.org/10.1007/s10806-018-9739-2

Rea, A. M. (1997). At the desert's green edge: An ethnobotany of the Gila River Pima. University of Arizona Press.

Rhodes, C. J. (2012). Feeding and healing the world: Through regenerative agriculture and permaculture. Science Progress, 95(4), 345-446. https://doi.org/10.3184/003685012X13504990668392

Rhodes, C. J. (2015). Permaculture: Regenerative_not merely sustainable. Science Progress, 98(4), 403-412. https://doi.org/10.3184/003685015X14467291596242

Rhodes, C. J. (2017). The imperative for regenerative agriculture. Science Progress, 100(1), 80-129. https://doi.org/10.3184/003685017X14876775256165

Rigby, D., \& Cáceres, D. M. (2001). Organic farming and the sustainability of agricultural systems. Agricultural Systems, 68(1), 21-40. https://doi.org/10.1016/S0308-521X(00)00060-3

Savory, A., \& Duncan, T. (2016). Regenerating agriculture to sustain civilization. In I. Chabay, M. Frick, \& J. Helgeson (Eds.), Land restoration: Reclaiming landscapes for a sustainable future (pp. 289-309). Academic Press. https://doi.org/10.1016/B978-0-12-801231-4.00023-9

Shilling, D. (2018). Introduction: The soul of sustainability. In M. K. Nelson \& D. Shilling (Eds.), Traditional ecological knowledge: Learning from Indigenous practices for environmental sustainability (pp. 3-14). Cambridge University Press.

Shiva, V. (2019). Monocultures of the mind. In The Vandana Shiva reader (pp. 71-112). The University Press of Kentucky.

Soloviev, E. R., \& Landua, G. (2016). Levels of regenerative agriculture. Terra Genesis International. https://ethansoloviev.com/wp-content/uploads/2019/02/Levels-of-Regenerative-Agriculture.pdf

Steward, P. R., Shackelford, G., Carvalheiro, L. G., Benton, T. G., Garibaldi, L. A., \& Sait, S. M. (2014). Pollination and biological control research: Are we neglecting two billion smallholders. Agriculture and Food Security, 3, Article 5. https://doi.org/10.1186/2048-7010-3-5

Thompson, J., \& Scoones, I. (2009). Addressing the dynamics of agri-food systems: An emerging agenda for social science research. Environmental Science \& Policy, 12(4), 386-297. https://doi.org/10.1016/j.envsci.2009.03.001

Tie, Y. C., Birks, M., \& Francis, K. (2019). Grounded theory research: A design framework for novice researchers. SAGE Open Medicine, 7, 1-8. https://doi.org/10.1177/2050312118822927

Trauger, A. (2017). We want land to live: Making political space for food sovereignty. University of Georgia Press.

Tsosie, R. (2017). Indigenous peoples and 'cultural sustainability': The role of law and traditional knowledge. In M. K. Nelson \& D. Shilling (Eds.), Traditional ecological knowledge: Learning from Indigenous methods for environmental sustainability (pp. 229-249). Cambridge University Press.

Turner, N. J., Ignace, M. B., \& Ignace, R. (2000). Traditional ecological knowledge and wisdom of Aboriginal peoples in British Columbia. Ecological Applications, 10(5), 1275-1287.

United Nations. (2010). 2010-2020: UN decade for deserts and the fight against desertification. http://www.un.org/en/events/desertification decade/whynow.shtml

VERBI Software. (2020). MAXQDA Analytics Pro 2020, Student (Version 3). https://www.maxqda.com/

Vizenor, G. (1994). Manifest manners: Narratives on postindian survivance. Bison Books.

Wall, D., \& Masayesva, V. (2019). People of the corn: Teachings in Hopi traditional agriculture, spirituality and sustainability. In D. A. Mihesuah \& E. Hoover (Eds.), Indigenous food sovereignty in the United States: Restoring cultural knowledge, protecting environments, and regaining health (pp. 209-222). University of Oklahoma Press.

Whyte, K. P. (2013). On the role of traditional ecological knowledge as a collaborative concept: A philosophical study. Ecological Processes, 2, Article 7. https://doi.org/10.1186/2192-1709-2-7

Whyte, K. P. (2017). What do Indigenous knowledges do for Indigenous peoples? In M. K. Nelson \& D. Shilling (Eds.), Traditional ecological knowledge: Learning from Indigenous methods for environmental sustainability (pp. 57-84). Cambridge University Press. https://doi.org/10.1017/9781108552998.005 
Whyte, K. P. (2018). Indigenous science (fiction) for the Anthropocene: Ancestral dystopias and fantasies of climate change crises. Environment and Planning E: Nature and Space, 1(1-2), 224-242. https://doi.org/10.1177/2514848618777621

Whyte, K., Brewer, J. P., \& Johnson, J. T. (2016). Weaving Indigenous science, protocols and sustainability science. Sustainable Science, 11(1), 25-32. https://doi.org/10.1007/s11625-015-0296-6

Wilson, S. (2008). Research is ceremony: Indigenous research methods. Fernwood.

World Commission on Environment and Development [WCED]. (1987). Report of the World Commission on Environment and Development: Our common future. United Nations, World Commission on Environment and Development. https://sustainabledevelopment.un.org/content/documents/5987our-common-future.pdf

Yetman, D., Búrquez, A., Hultine, K., \& Sanderson, M. (2020). The saguaro cactus: A natural history. The University of Arizona Press.

Youngberg, G., \& DeMuth, S. P. (2013). Organic agriculture in the United States: A 30-year retrospective. Renewable Agriculture and Food Systems, 28(4), 294-328. https://doi.org/10.1017/S1742170513000173

Zari, M. P. (2018). Regenerative urban design and ecosystem biomimicry. Routledge. 
Appendix A.

Table A1. Comparing Regenerative Agriculture, Agroecology, Permaculture, Food System Sustainability and Food Sovereignty

\begin{tabular}{|c|c|c|c|c|c|}
\hline & Regenerative Agriculture & $\begin{array}{l}\text { Agroecology (Altieri, 2002; } \\
\text { Gliessman, 2007) }\end{array}$ & $\begin{array}{l}\text { Permaculture (Mollison, 1990; } \\
\text { Holmgren, 2007) }\end{array}$ & $\begin{array}{l}\text { Food System Sustainability } \\
\text { (Eakin et al., 2017) }\end{array}$ & $\begin{array}{l}\text { Food Sovereignty-Radical } \\
\text { Collectivism (Trauger, 2017) }\end{array}$ \\
\hline Definition & $\begin{array}{l}\text { To embrace regenerative } \\
\text { development, by adopting } \\
\text { measures that drive the } \\
\text { regeneration of soils, } \\
\text { forests, watercourses, and } \\
\text { the atmosphere (Rhodes, } \\
2017 \text { ). }\end{array}$ & $\begin{array}{l}\text { The holistic study of agro- } \\
\text { ecosystems, which includes } \\
\text { environmental and human } \\
\text { elements, with a focus on } \\
\text { form, dynamics and func- } \\
\text { tions of their interrelation- } \\
\text { ships and the processes in } \\
\text { which they are involved } \\
\text { (Altieri, 2002). }\end{array}$ & $\begin{array}{l}\text { Derived from permanent } \\
\text { agriculture or culture and } \\
\text { describes a low-impact } \\
\text { method that uses perennial } \\
\text { cultivation methods to pro- } \\
\text { duce food crops, working via } \\
\text { principles that are in } \\
\text { harmony with nature. }\end{array}$ & $\begin{array}{l}\text { Achieves and maintains } \\
\text { food security under uncer- } \\
\text { tain and dynamic social- } \\
\text { ecological conditions, } \\
\text { through respecting and } \\
\text { supporting the context- } \\
\text { specific cultural values and } \\
\text { decision-processes that give } \\
\text { food social meaning, and } \\
\text { the integrity of the social- } \\
\text { ecological processes neces- } \\
\text { sary for food provisioning } \\
\text { today and for future } \\
\text { generations. }\end{array}$ & $\begin{array}{l}\text { Food sovereignty is the right } \\
\text { of peoples to healthy and } \\
\text { culturally appropriate food } \\
\text { produced through ecologi- } \\
\text { cally sound and sustainable } \\
\text { methods, and their right to } \\
\text { define their own food and } \\
\text { agriculture systems (Nyéléni } \\
\text { Declaration, 2007). }\end{array}$ \\
\hline Goal & $\begin{array}{l}\text { To increase soil quality and } \\
\text { biodiversity in farmland } \\
\text { while producing nourishing } \\
\text { farm products profitably } \\
\text { (LaCanne, Lundgren, 2018). }\end{array}$ & $\begin{array}{l}\text { Provide basic ecological } \\
\text { principles for how to study, } \\
\text { design, and manage agro- } \\
\text { ecosystems that are both } \\
\text { productive and natural- } \\
\text { resource conserving, and } \\
\text { that are also culturally } \\
\text { sensitive, socially just, and } \\
\text { economically viable (Altieri, } \\
\text { 1995). }\end{array}$ & $\begin{array}{l}\text { To develop sustainable } \\
\text { human settlements and } \\
\text { self-maintained agricultural } \\
\text { systems modelled from } \\
\text { natural ecosystems } \\
\text { (Rhodes, 2017). }\end{array}$ & $\begin{array}{l}\text { To ensure food security as } \\
\text { well as social justice. }\end{array}$ & $\begin{array}{l}\text { To put the aspirations and } \\
\text { needs of those who pro- } \\
\text { duce, distribute, and con- } \\
\text { sume food at the heart of } \\
\text { food systems rather than at } \\
\text { the demands of corpora- } \\
\text { tions. Prioritize local } \\
\text { economies and markets and } \\
\text { empower peasant and } \\
\text { family farmer-driven } \\
\text { agriculture, and artisanal } \\
\text { food production, } \\
\text { distribution, and consump- } \\
\text { tion based on environ- } \\
\text { mental, social and eco- } \\
\text { nomic sustainability (Nyéléni } \\
\text { Declaration, 2007). }\end{array}$ \\
\hline
\end{tabular}




\begin{tabular}{|c|c|c|c|c|c|}
\hline Principles & $\begin{array}{l}\text { 1. Activitly build soil fertility } \\
\text { and avoid tillage. } \\
\text { 2. Foster plant diversity on } \\
\text { the farm. } \\
\text { 3. Integrating livestock and } \\
\text { cropping operations on } \\
\text { the land. } \\
\text { 4. Integrate diversity in } \\
\text { terms of polycultures } \\
\text { and perennials. }\end{array}$ & $\begin{array}{l}\text { 1. Resilient systems that } \\
\text { cope with disturbances. } \\
\text { 2. Species and genetic } \\
\text { diversification in space } \\
\text { and time. } \\
\text { 3. Enhance soil biotic activity } \\
\text { for plant growth. } \\
\text { 4. Sociocultural relations of } \\
\text { collective forms of } \\
\text { organization. } \\
\text { 5. Increased soil cover. } \\
\text { 6. Balancing nutrient cycle } \\
\text { and recycling of biomass. } \\
\text { 7. Optimization of the whole } \\
\text { farm, not one crop. }\end{array}$ & $\begin{array}{l}\text { 1. Use and value diversity. } \\
\text { 2. Obtain a yield. } \\
\text { 3. Creatively use and } \\
\text { respond to change. } \\
\text { 4. Apply self-regulation and } \\
\text { accept feedback. } \\
\text { 5. Use and value renewable } \\
\text { resources and services. } \\
\text { 6. Use edges and value the } \\
\text { marginal. } \\
\text { 7. Design from patterns to } \\
\text { detail. } \\
\text { 8. Integrate rather than } \\
\text { segregate. } \\
\text { 9. Use small and slow } \\
\text { solutions. } \\
\text { 10. Catch and store energy. } \\
\text { 11. Produce no waste. }\end{array}$ & $\begin{array}{l}\text { 1. Innovation. } \\
\text { 2. Diversity in terms of } \\
\text { crops, diet, and practices. } \\
\text { 3. Congruence is about fit. } \\
\text { 4. Transparency. } \\
\text { 5. Modularity. }\end{array}$ & $\begin{array}{l}\text { 1. The right of people to self- } \\
\text { governance and } \\
\text { democracy. } \\
\text { 2. Local production, food } \\
\text { coops, solidarity econo- } \\
\text { mies, local processing. } \\
\text { 3. Mutualisms and alternative } \\
\text { economic models. } \\
\text { 4. Based on agroecological } \\
\text { principles. } \\
\text { 5. Access to local and com- } \\
\text { munal resources, seeds } \\
\text { varieties, water, land. } \\
\text { 6. Social justice and self- } \\
\text { governance. }\end{array}$ \\
\hline
\end{tabular}




\section{Appendix B.}

\section{Figure B1. Life's Principles Diagram}

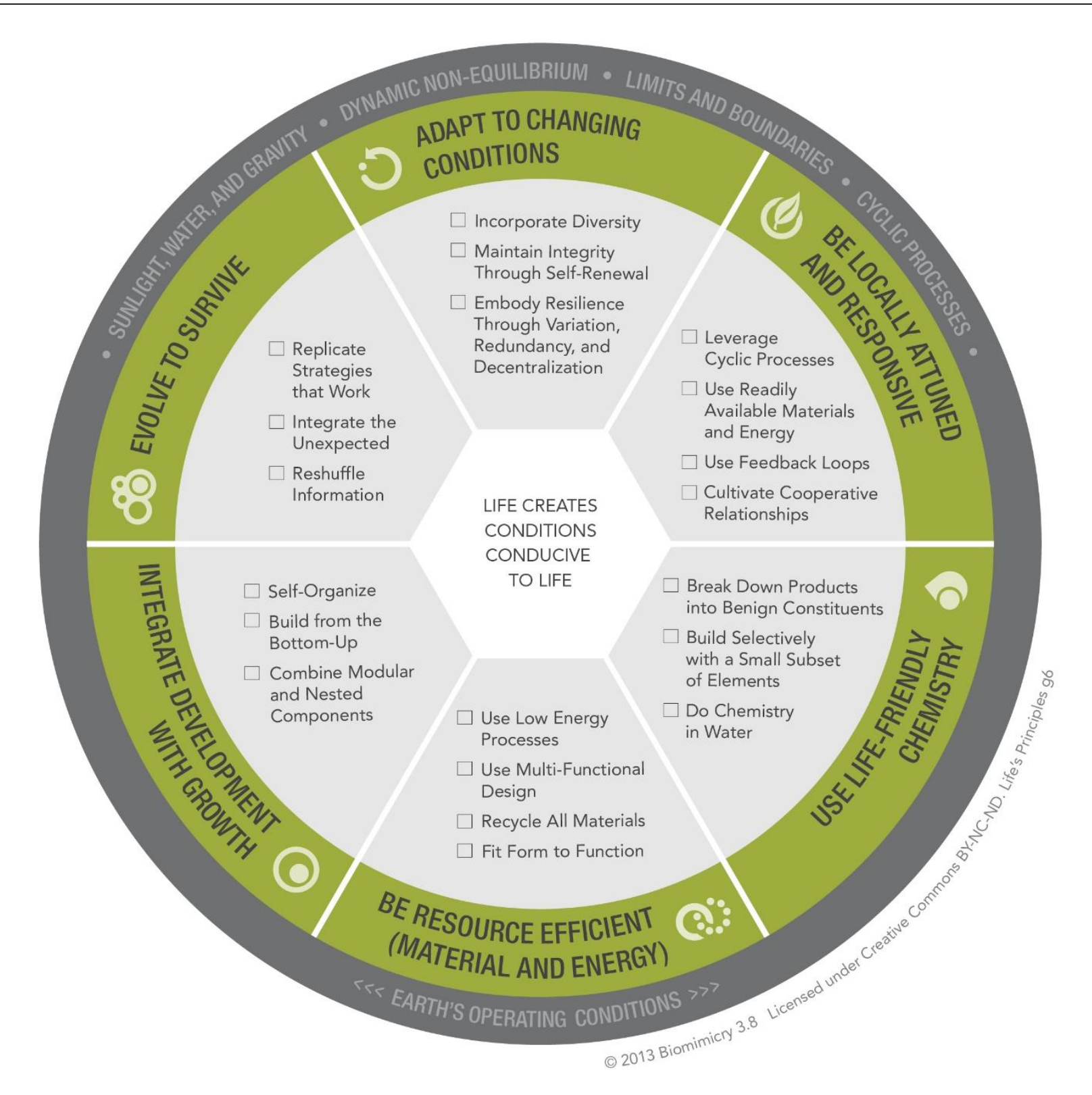

Source: Copyright @ 2013 by Biomimicry 3.8; reprinted under Creative Commons license CC-BY-NC-ND. 
Appendix C.

Figure C1. Framework for Traditional Ecological Knowledge and Wisdom of Native People

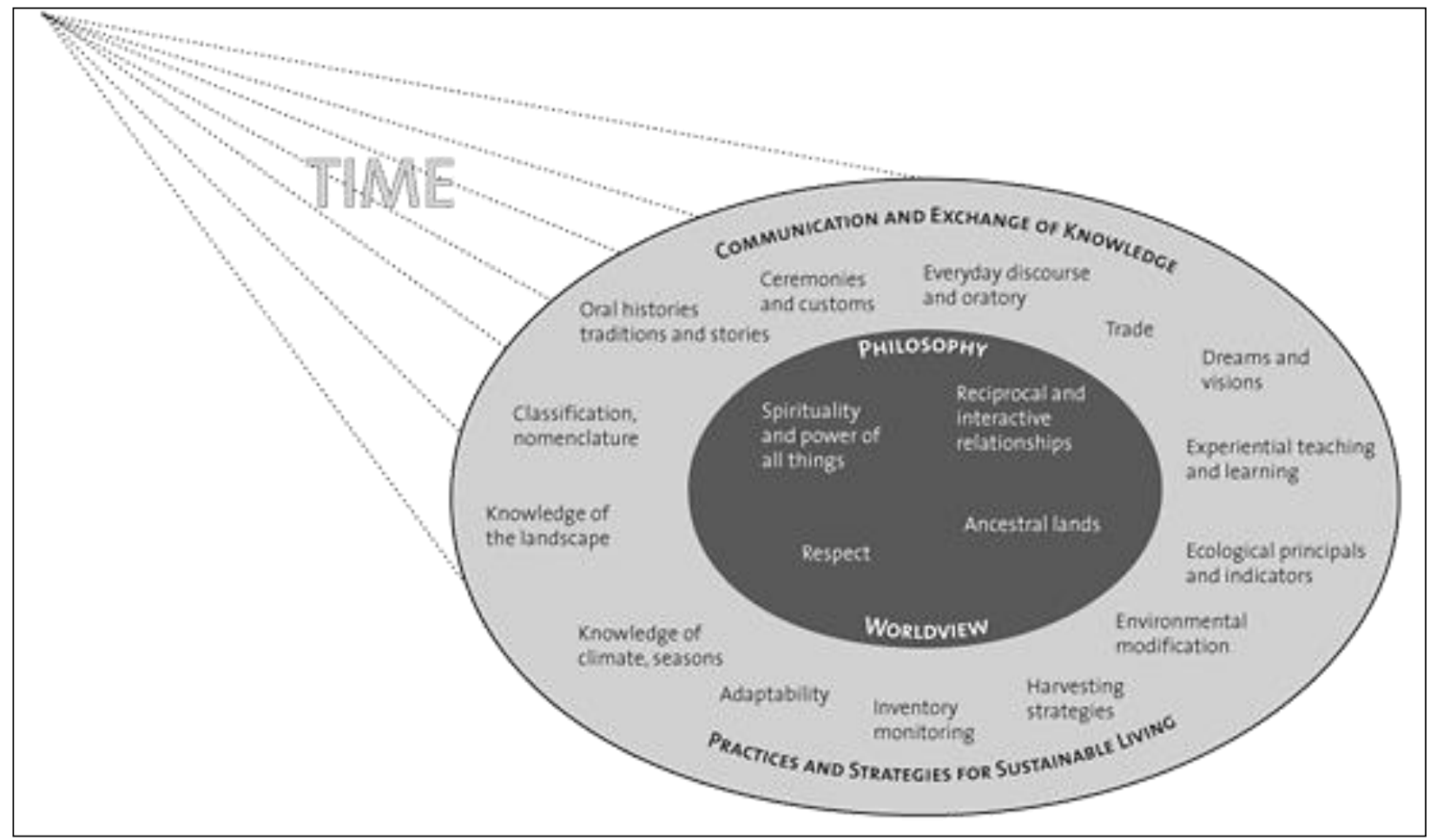

Source: Turner, Ignace, \& Ignace, 2000; reprinted with permission from John Wiley \& Sons. 


\section{Appendix D.}

\section{Table D1. Titles, Dates and Organizers of Various Workshops Attended}

\begin{tabular}{lll}
\hline Title of Workshops & Dates & Organizers/Presenters \\
\hline Reclaiming Native Truths, Slow Food Nations & July 19, 2019 & $\begin{array}{l}\text { Michael Roberts, lan McFaul, Denisa } \\
\text { Livingston, Roy Kady }\end{array}$ \\
\hline The Art of Fermentation, Slow Food Nations & July 20, 2019 & Sandor Katz, Mara King \\
\hline $\begin{array}{l}\text { Indigenous Sustainable Communities Design Course } \\
\text { (ISCDC) }\end{array}$ & July 21-30, 2019 & $\begin{array}{l}\text { Clayton Brascoupe, Louie Hena, Roxanne } \\
\text { Swentzl, Lillian Hill }\end{array}$ \\
\hline Wisdom of Indigenous Foodways & January 22, 2020 & Janie Hipp, Melissa Nelson, Sean Sherman, \\
& & $\begin{array}{l}\text { Twila Cassadore, Terrol Dew Johnson, } \\
\text { Michael Johnson }\end{array}$ \\
\hline Rights of Nature and the Food system & January 23, 2020 & Janie Hipp Paula Daniels, Denisse Córdova \\
& & Montes, Shannon Biggs \\
\hline Intertribal Food Summit & June 20, 2020 & Melissa Nelson, Linda Black Elk \\
\hline Indigenous Innovation Workshop & June 15-19 2020 & Sunny Dole, Diné, Karletta Chief \\
\hline Indigenous Governance & July 20-26, 2020 & Lyla June \\
\hline
\end{tabular}

